HUMAN RIGHTS IN PRESIDENTIAL DEMOCRACIES:

DOES A RUNOFF RULE REDUCE REPRESSION?

\author{
A Dissertation \\ presented to \\ the Faculty of the Graduate School \\ at the University of Missouri-Columbia
}

In Partial Fulfillment

of the Requirements for the Degree

Doctor of Philosophy

by

JOSHUA HOLZER

Dr. Jonathan Krieckhaus, Dissertation Supervisor

MAY 2019 
(C) Copyright by Joshua Holzer All Rights Reserved 
The undersigned, appointed by the dean of the Graduate School, have examined the dissertation entitled:

\section{HUMAN RIGHTS IN PRESIDENTIAL DEMOCRACIES: DOES A RUNOFF RULE REDUCE REPRESSION?}

presented by Joshua Holzer,

a candidate for the degree of Doctor of Philosophy

and hereby certify that, in their opinion, it is worthy of acceptance.

Professor Jonathan Krieckhaus

Professor Moisés Arce

Professor Jay Dow

Professor William H. Meyers 
To my family, without whom none of this would have been possible 


\section{Acknowledgements}

Much of this dissertation reproduces or relies upon the following sole-authored works:

- "Democratic presidential elections and human rights: does a runoff round reduce repression?," published in The International Journal of Human Rights (Taylor \& Francis).

- "The perils of plurality rule and the major(itarian) effect of cabinet composition on human rights in presidential democracies," published in Research \& Politics (Sage).

- "Measuring presidential centrism and its effect on repression: does ideology influence whether democratic governments respect human rights?," forthcoming in Political Science (Taylor \& Francis).

- "When justice answers to the president: reexamining the effect of cabinet partisanship on human rights in presidential democracies," forthcoming in The Social Science Journal (Elsevier).

First, I would like to thank Elsevier, Sage, and Taylor \& Francis for allowing me to reprint parts of these papers. Second, each of these papers were significantly improved by all the feedback I received through numerous rounds peer-reviewer. As such, I would 
like to thank the reviewers at each of the aforementioned journals. I wish I could be more specific — as some comments in particular were very helpful—but alas, these comments were all anonymous.

Prior to getting this papers accepted at journals, I presented most of them at various meetings of the International Studies Association (ISA) throughout 2015-2018. As such I would next like to thank all those that provided comments and feedback at each of the ISA conferences I attended.

The earliest version of this dissertation started as a research design I did in Amanda Murdie's Human Security class. We had just read Richards and Gelleny (2007), and I had asked a question in class about the potential influence of runoff elections on human rights. She said, "I don't know... go research that!" I have spent the last four years trying to find the answer my own in-class question, and this dissertation is the culmination of this effort. I would like to thank Amanda Murdie for offering her amazing class, as well as the time she spent providing comments on my early drafts.

I would also like to thank my advisor, Vanya Krieckhaus. In addition to providing comments on various drafts, he also (perhaps more importantly) entertained the notion that I could turn those early drafts into a dissertation. As mentioned, at this point, parts of this dissertation have appeared (or will appear) in no less than four different academic outlets. Four years ago, however, I was simply a headstrong student with a class paper. Vanya took a chance by humoring my stubborn nature and granting me unfettered freedom to pursue my research interests. Without Vanya, I would not have been able to write this dissertation the way that I have. Vanya was always there for support whenever I needed him, and I would not have wanted anyone else as an advisor. 
Next, I would like to thank my committee. I defended my dissertation proposal back in October of 2017. Amazingly, my dissertation is very similar to what I had initially proposed; however, completing this dissertation was far more difficult than I expected. Namely, I had anticipated that all of the data I would need would be readily available. In actuality, I ended up having to spent nearly a year coding what I needed. Throughout this time, the only update I could provide my committee is that I was 'still gathering data.' My committee members, in turn, simply had to trust that I would eventually finish and that all the time I had spent would actually be worthwhile. Thankfully, throughout this process, I have had a committee readily willing to provide help when needed, but also willing to provide time and space as necessary.

Finally, I would like to thank my friends and family. First, I would like to thank Steve Gilpin who has helped by providing the occasional distraction from this dissertation. Additionally, I would like to thank Sam, Isaac, and Cassy Holzer for all of their encouragement over the years. Next, I would like to thank David and Deborah Holzer for helping me to focus on research by supporting me in more ways than I can count. Lastly, I would like to thank Sera Chiuchiarelli. Throughout much of this process, I have been absent in order to do research. At other times, I have been present, but have been either stressed, anxious, or otherwise unpleasant to be around. Throughout all of this, you have remained a positive presence, and without you, it is possible that I never would have made it this far. 


\section{TABLE OF CONTENTS}

Acknowledgements

List of Figures

vii

List of Tables

viii

$\begin{array}{ll}\text { Abstract } & \mathbf{x} \\ & \end{array}$

1 Introduction $\quad 1$

1.1 An emphasis on presidential democracies . . . . . . . . . . . 4

2 Theory $\quad 8$

2.1 Outcomes of a presidential runoff rule . . . . . . . . . . 10

2.1.1 A reduced distance between the ideological position of the president and the median voter $\ldots \ldots \ldots \ldots 11$

2.1.2 A reduced percent of the cabinet in the same party as the president 15

2.1.3 A reduced likelihood that the president is elected without a majority 20

2.2 Determinants of government respect for human rights . . . . . . . . . . 21

2.2.1 The downside of a large distance between the ideological position of the president and the median voter ........... 21 
2.2.2 The downside of cabinets comprised of a high percent of members in the same party as the president $\ldots \ldots \ldots \ldots$

2.2.3 The downside of presidents elected without a majority . . . . . 27

2.3 Presidents elected using a runoff rule $\ldots \ldots \ldots \ldots \ldots$

3 Research Design 32

$3.1 \quad$ Sample . . . . . . . . . . . . . . . . . 33

3.2 Dependent variable $\ldots \ldots \ldots \ldots \ldots \ldots \ldots \ldots \ldots$

3.3 Independent variables $\ldots \ldots \ldots \ldots \ldots \ldots \ldots \ldots$

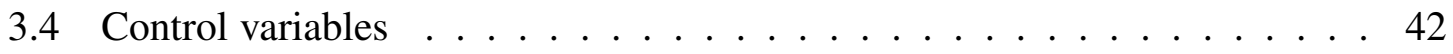

4 Results $\quad 47$

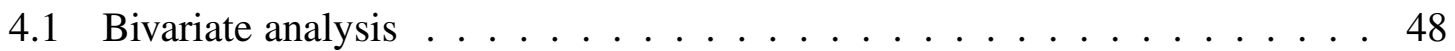

4.2 Regression analysis . . . . . . . . . . . . . . . . 52

4.3 Substantive effects $\ldots \ldots \ldots \ldots \ldots \ldots \ldots \ldots$

5 Conclusion $\quad 64$

5.1 An (re)emphasis on democracies $\ldots \ldots \ldots \ldots \ldots \ldots$

$\begin{array}{ll}\text { Appendix } & 71\end{array}$

$\begin{array}{ll}\text { Bibliography } & 78\end{array}$

$\begin{array}{ll}\text { Vita } & 97\end{array}$ 


\section{List of Figures}

2.1 Two-candidate election with defection . . . . . . . . . . . . 12

2.2 Two-candidate election without defection . . . . . . . . . . 13

2.3 Three-candidate election without defection . . . . . . . . . . . 13

2.4 Three-candidate election with defection . . . . . . . . . . . . 13

2.5 Three-candidate election with defection and runoff $\ldots \ldots \ldots$

2.6 The relationship between centripetal political systems, the president's distance from the median voter, and good governance. . . . . . . . . . . 23

2.7 The relationship between pre-election bargaining, the percent of the cabinet in the same party as the president, and the introduction of veto players. 26

2.8 The relationship between a large minimum winning coalition, presidents elected without a majority, and the provision of public goods. . . . . . . . 29

2.9 The relationship between presidents elected using a runoff rule and government respect for human rights. . . . . . . . . . . . . 31

3.1 The president's distance from the median voter in 14 democracies. . . . . 40 


\section{List of Tables}

2.1 The 2007 Presidential election in East Timor . . . . . . . . . . . 18

3.1 Comparing CIRI versus PTS coding. . . . . . . . . . . . . . . 34

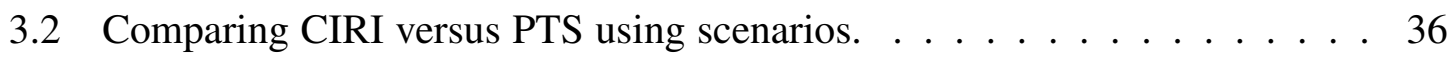

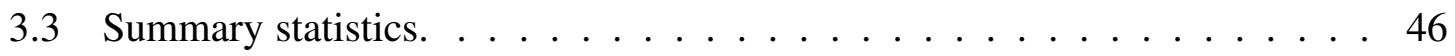

4.1 Testing the equality of variances between the president being elected using a runoff rule and the president's distance from the median voter. . . . . . 49

4.2 Testing the relationship between the president being elected using a runoff rule and the president's distance from the median voter using a two-sample $t$-test (with equal variances). . . . . . . . . . . .

4.3 Testing the equality of variances between the president being elected using a runoff rule and the percent of the cabinet in the same party as the president. 50

4.4 Testing the relationship between the president being elected using a runoff rule and the percent of the cabinet in the same party as the president using

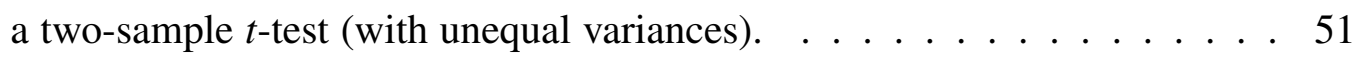

4.5 Testing the relationship between the president being elected using a runoff rule and the president being elected without a majority using Fisher's exact

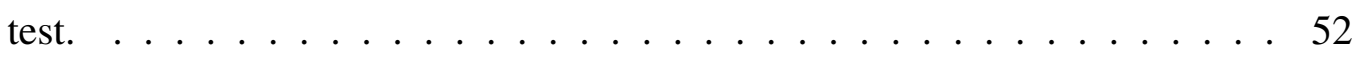


4.6 Ordered logit estimates of CIRI scores in presidential democracies, 1990-

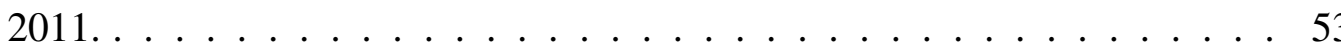

4.7 Summary statistics of scenarios used in predicted probabilities analysis. . . 56

4.8 The percentage change in predicted probabilities of CIRI scores when the president's distance from the median voter is at the maximum versus min-

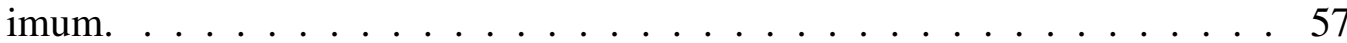

4.9 The percentage change in predicted probabilities of CIRI scores when the percent of the cabinet in the same party as the president is at $100 \%$ versus

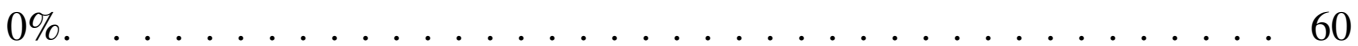

4.10 The percentage change in predicted probabilities of CIRI scores when the president is elected without a majority versus is elected with a majority. . . 61

4.11 The percentage change in predicted probabilities of CIRI scores when the president is elected using a runoff rule versus is not elected using a runoff

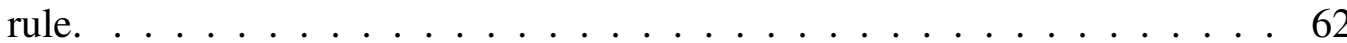

5.1 An additional ordered logit estimate of CIRI scores in presidential democ-

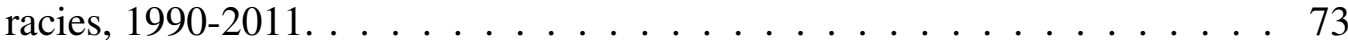

5.2 The percentage change in predicted probabilities of CIRI scores when the justice minister is in the same party as the president versus the justice minister is not in the same party as the president. . . . . . . . . . . . 75 


\section{Abstract}

I argue that within a democratic context the presence of a presidential runoff rule leads to the following outcomes: a reduced distance between the ideological position of the president and the median voter, a reduced percent of the cabinet in the same party as the president, and a reduced likelihood that the president is elected without a majority. Additionally, I argue that a large distance between the ideological position of the president and the median voter, cabinets comprised of a high percent of members in the same party as the president, and presidents elected without a majority are all negatively associated with high government respect for human rights. Since the presence of a runoff rule reduces determinants that are in turn negatively associated with high government respect for human rights, the presence of a runoff rule is likely positively associated with high government respect for human rights. Ultimately, I find that democratic presidential elections held using a runoff rule produce presidents that are less likely to be associated with lower government respect for human rights, and more likely to be associated with greater government respect for human rights. In order to promote government respect for human rights, I suggest that constitutional designers embrace the idea of instituting a presidential runoff rule. Simply put: a relatively easy way to reduce repression is to add the possibility of a runoff round to all democratic presidential elections. 
Chapter 1

\section{Introduction}


Famed political scientist Alexis de Tocqueville was among 16 delegates chosen to draft the French Constitution of 1848. Having just emerged from monarchy, Tocqueville feared that when "the whole administration of the country, in matters of the greatest and of the smallest moment, belonged to the President... what could a President elected by the people be other than a pretender to the Crown?" (Tocqueville 1896: 248). Within committee, he argued that "[t]he office could only suit those who hoped to make use of it in order to assist in transforming the Presidential into Royal powers" (Tocqueville 1896: 248-249). Nearly all of the committee, however, saw a directly elected president as non-negotiable; Tocqueville, therefore, "endeavoured at least to make its application less dangerous" (Tocqueville 1896: 251).

To begin, Tocqueville (1896: 251) "first proposed to limit in various directions the sphere of the Executive Power; but... soon saw that it was useless to attempt anything serious on that side." Next, Tocqueville (1896: 251) "fell back upon the method of election itself," for instance by proposing a rule requiring a runoff election "if an absolute majority was not obtained at the first vote." He cautioned that if "a relative majority [i.e. a mere plurality] was to be sufficient to make the election valid, it might be possible that the President should only represent the wishes of a minority of the nation" (Tocqueville 1896: 251-252). Unfortunately, however, many of Tocqueville's wiser amendments were rebuffed. "Let us adopt" the committee argued, then "afterwards... we can judge from this sketch how to fix the definitive features" (Tocqueville 1896: 256). "But we did not retrace our steps," Tocqueville laments, "and the sketch remained the picture" (Tocqueville 1896: 256). 
Roughly one month after the ratification of the French Constitution of 1848, France held its first-ever president election. The victor of this election was Louis-Napoléon Bonaparte, the nephew of Napoléon Bonaparte. Nearly four years later, Louis-Napoléon's term as France's first president was coming to a close. Instead of leaving office, in December of 1851, Louis-Napoléon staged a self-coup d'état by dissolving the National Assembly and sending French troops to occupy strategic points throughout Paris. Any organized opposition to Louis-Napoléon's coup was quickly suppressed by French troops, with an estimated 300-400 being killed (Milza 2004: 261). As Louis-Napoléon consolidated control during the period that followed, "[a]ltogether 26,884 arrests were effected throughout France" of which "9,000 were transported to Algeria and 239 to Cayenne," French Guiana where a penal colony was purpose-built to house political prisoners (Cobban 1992: 158).

Within a year, Louis-Napoléon followed his uncle's footsteps in becoming Emperor of the French. While the broad avenues of Paris are an enduring legacy of the selfstyled Napoléon III, so too is Cayenne's Devil's Island prison complex, which serves as a stark reminder that France's experiment with having the president "elected directly was as new as it was dangerous" (Tocqueville 1896: 248). The French Constitution of 1852 repealed the Constitution of 1848, and established the French Second Empire. Perhaps if Tocqueville's proposals had been adopted, France's first president would not have lead the new democracy straight into a repressive dictatorship.

In 1962 the French voted on a proposed change to the French Constitution of 1958 to re-introduce direct presidential elections. Given how the last directly-elected president fared, there was reluctance in France to return to a system where a leader with authoritarian aspirations could obtain power with a mere plurality of the vote. To assuage such 
concerns, the 1962 referendum proposed that direct presidential elections be held using a runoff rule, a 'novel' idea at the time, despite having been first proposed by Tocqueville over 100 year earlier. Since the adoption of a runoff rule, France has yet to elect another dictator, perhaps vindicating Tocqueville, who sought to minimize the risks associated with directly electing the holder of such a powerful office. ${ }^{1}$ Today, "[t]he runoff electoral system is the single most used electoral system for presidential elections"(Bouton 2013: 1248). This system is "especially prevalent among those regimes that previously had presidents elected by plurality, but then lapsed into a period of authoritarianism" (Shugart and Taagepera 1994: 323-324). The thought seems to be that perhaps a runoff rule would give citizens two chances - instead of one-to avoid accidentally electing a leader with authoritarian aspirations. Recent research, however, argues that "[t]he need for runoff elections is dubious" (Pérez-Liñán 2006: 129). In this dissertation, I seek to counter this claim, as I posit that a runoff rule promotes the protection of human rights by reducing outcomes that are negatively associated with high government respect for human rights.

\subsection{An emphasis on presidential democracies}

Before proceeding, I want to note that in this dissertation, I only examine the effects of democratic elections in presidential systems. First, previous studies that focus on the effect of election laws on human rights have already noted a difference between parliamentary and presidential systems (e.g., Richards and Gelleny 2007; Cingranelli and Filippov 2010). These findings align with Huntington (1964), who argues that a state's

\footnotetext{
${ }^{1}$ Furthermore, opposing the president of France no longer leads to a term on Devil's Island, as the famed prison complex has been repurposed as a tourist attraction, which serves to remind visitors that a single vote can separate democracy and dictatorship.
} 
political system conditions whether it will resort to repression. By only examining pres-

idential systems, I clearly establish empirical boundaries for this study, allowing me to focus on differences within presidential systems, rather than between presidential systems and other forms of government. Second, while explaining repression in non-democracies is certainly important, repression that occurs within a non-democracy is not particularly surprising. I am interested in why democracies-which nominally reflect the will of the people (and therefore, should be less likely to repress their people)—still resort to repression. While democracies, for example, are generally more inclined to protect human rights and limit the use of repression vis-à-vis non-democracies, repression still occurs. ${ }^{2}$ Why is this the case? It is for this reason, that I further limit the scope of this study to democracies. $^{3}$

Montesquieu argues that "constant experience shows us that every [individual] invested with power is apt to abuse it, and to carry [their] authority as far as it will go... To prevent abuse [therefore], it is necessary from the very nature of things that power should be a check to power" (Cohler, Miller, and Stone (1989: 69). If a president can be elected by only relying on a narrow plurality of the vote, what incentive do they have to protect the rights of a large majority of the population? If that narrow plurality that elected the

${ }^{2}$ For examples of such literature, see: Fein (1995); Krain (1997); Davenport (1999); Poe, Tate, and Keith (1999); Zanger (2000); Harff (2003); Richards, Webb, and Clay (2015).

${ }^{3}$ It it worth noting that there is a whole body of literature that argues that elections serve a very different purpose within non-democracies versus democracies. For instance, many scholars, view authoritarian elections as an institutional tool that dictators can use to co-opt elites (Boix and Svolik 2013), party members (Magaloni 2006), or larger groups within society (Gandhi and Przeworski 2006; Gandhi 2008; Wright 2008). Elites may perceive elections a fairer method of spoil distribution than appointments, and therefore, in such systems, obtaining political office is dependent upon an individual's ability buy and persuade voters (Lust-Okar 2006). In this way, the dictator can ensure that the most "popular" elites are associated with the regime and that they do not become complacent in serving the regime's goals. Finally, authoritarian elections can be used by incumbents as a tool to deter defection among members of the ruling coalition. Essentially, an autocrat could rig an election overwhelmingly in his or her favor, so as to send a signal to members of the elite that any opposition would be pointless (Magaloni 2006). 
president only reflects the ideological fringes of that society, what prevents the president from only catering to the excesses of the extremes? If, after the election, a president is able to appoint party loyalist to all top positions of power, to paraphrase Montesquieu, power would not be checking power.

However, if a president is forced to win over a majority of the population (which a runoff rule would require), then the president would have a clear incentive to protect the majority of the population responsible for electing him or her. If a president is forced to campaign down the centre in order to have a realistic shot at winning that majoritarian runoff election, then upon winning, they have clear incentive to represent the moderates in the middle, as opposed to the radicals at of the far left or far right. If, in order to obtain an advantage leading up to the runoff election, a president is incentivized to make deals for support that end up empowering members of opposing parties with cabinet-level positions, then power can be checked with power.

Scholars have long homed-in on variation among constitutional structure as a factor which influences a regime's propensity to repress. ${ }^{4}$ The idea that different presidential regimes have different institutional characteristics is also not new (Duverger 1970, 1980). However, despite advances in the comparative literature's conceptualization of different presidential systems, the trend within human rights scholarship has been to treat all presidential states the same. ${ }^{5}$ This study sheds light on how they are different, as I argue that states that use a presidential runoff rule are more likely to be associated with high government respect for human rights versus states that do not use a runoff rule.

\footnotetext{
${ }^{4}$ See, for example, the following: Davenport (1996a); Keith (2002a); Mitchell, Ring, and Spellman (2013). ${ }^{5}$ Examples of this trend include: Davenport (1997); Richards (1999); Richards and Gelleny (2007); HafnerBurton, Hyde, and Jablonski (2014).
} 
The remainder of this dissertation is organized as follows: in Chapter 2, I outline my theoretical argument, which consists of six premises, which together build up to my hypothesis (which, again, is that the presence of a presidential runoff rule is positively associated with high government respect for human rights); in Chapter 3, I discuss the sample and variables I used to test by my hypothesis (as well as my premises); In Chapter 4, I test my hypothesis (as well as my premises), I discuss the results, and I discuss substantive effects; and finally, in Chapter 5, I conclude. 


\section{Chapter 2}

\section{Theory}


An enduring goal of political science has been an understanding of why states repress. The general purpose of this literature has been to identify the particular political, economic, and social conditions that either encourage or discourage governments from violating the rights of their citizens. Instigated by the development and proliferation of international human rights law and reporting, human rights scholars have begun statistically modeling government respect for human rights in an attempt to empirically explain why some governments, or government types, resort to human rights repression while others do not. ${ }^{1}$

Parallel to these developments, many comparativists have been focusing their research on the predictable consequences of electoral systems. ${ }^{2}$ This body of literature uses phrases such as 'electoral engineering,' which indicates a sense among scholars that institutions can be used to shape outcomes. ${ }^{3}$ Sartori (1968: 273), for instance, asserts that electoral rules can be purposively designed to achieve particular outcomes, as they are "the most specific manipulable instrument of politics." Lijphart (1995: 412) adds that "[i]f one wants to change the nature of a particular democracy, the electoral system is likely to be the most suitable and effective instrument for doing so."

Recently, these two literatures have begun to intersect as comparativists have begun examining the causes of human rights repression, while human rights scholars have ${ }^{1}$ For an overview of this literature, see the following: McKinlay and Cohan $(1975,1976)$; Strouse and Claude (1976); Ziegenhagen (1986); Park (1987); Boswell and Dixon (1990); Davis and Ward (1990); Alfatooni and Allen (1991); McNitt (1995); Regan (1995); Davenport (1996b); Gartner and Regan (1996); Meyer (1996); Cingranelli and Richards (1999a, 1999b); Keith (1999); Smith, Bolyard, and Ippolito (1999); Apodaca (2001); Hathaway (2002); Walker and Poe (2002); Hafner-Burton and Tsutsui (2005, 2007); Hafner-Burton (2008); Conrad and Moore (2010); Murdie and Davis (2010); Sorens and Ruger (2012); Cingranelli, Fajardo-Heyward, Filippov (2014).

${ }^{2}$ For instance, see the following: Duverger (1954); Taagepera and Shugart (1989); Lijphart (1994); Cox (1997).

${ }^{3}$ For an overview of this literature, see the following: Lijphart (1977, 1984); Horowitz (1991); Sartori (1994); Reynolds (1999); Reilly (2001, 2002); Norris (2004). 
begun looking to electoral institutions as possible explanatory variables. Cingranelli and Filippov (2010: 246), for instance, argue that "certain characteristics of electoral rules are associated with better human rights practices." I seek to build upon this idea that electoral rules affect government respect for human rights by hypothesizing that a presidential runoff rule promotes high government respect for human rights. My theoretical argument is divided into six premises which together build up to my hypothesis. In the first section of this chapter, I outline my first three premises, which are all outcomes of a presidential runoff rule. In the next section, I outline my remaining three premises, which detail how each of the outcomes in the preceding section are all negatively associated with high government respect for human rights. In the third and final section, I hypothesize that if a runoff rule reduces outcomes that are negatively associated with high government respect for human rights, then a runoff rule should be positively associated with government respect for human rights.

\subsection{Outcomes of a presidential runoff rule}

Presidential runoff elections have taken place throughout the world, including in Western Europe, Eastern Europe, Latin America, Africa, and Asia. Runoff elections are particular common in newly-democratic post-colonial states as a legacy of France, which adopted the runoff for presidential elections in a 1962 referendum. ${ }^{4}$ However, at present, there is "scant empirical literature on majority runoff elections" (Bouton and Gratton 2015: 284). As such, "[d]espite its increasing popularity, not much is known about the effect of

\footnotetext{
${ }^{4}$ Villalón and Idrissa (2005: 33) note that upon independence, "[i]n virtually all of the Francophone countries...the choice was made by default: the institutions of democracy were to be modelled on...the French constitution."
} 
the runoff system" (Bordignon, Nannicini, and Tabellini 2017: 123). The extant literature does, however, suggests that a presidential runoff rule should lead to at least three outcomes, which I will discuss in this section. First, the presence of a runoff rule reduces the ideological distance between the president and the median voter. Second, the presence of a runoff rule reduces the percentage of cabinet members in the same party as the president. Finally, the presence of a runoff rule reduces the likelihood that the president is elected without a majority.

\subsubsection{A reduced distance between the ideological position of the pres-}

\section{ident and the median voter}

The study of rational voting largely begins with Downs' (1957) median voter theorem, which suggests that in a two-candidate race, each politician is incentivized to converge on the ideological position of the median voter in order to maximize their vote share..$^{5}$ For instance, in Figure 2.1, Candidate 1 is located at the ideological position of the median voter, while Candidate 2 has 'defected' (i.e. chosen a position other than that of the median voter). Downs (1957) argues that rational voters vote for the candidate to which they are ideologically closest. Therefore, all the voters to the left of Candidate 1 vote for Candidate 1, all the voters to the right of Candidate 2 vote for Candidate 2, and all the voters between Candidate 1 and 2 each vote for the candidate to which they are closest. In the end, Candidate 1 wins the election with over $50 \%$ of the vote, while Candidate 2

\footnotetext{
${ }^{5}$ The case could be made the spatial voting literature actually begins with Hotelling (1929). He argues that if two companies where given a choice of location on a straight line evenly dispersed with customers, it is rational for both companies to locate at the exact middle. Hotelling (1929: 54) suggests that the same intuition applies to political campaigning, as "each party strives to make its platform as much like the other as possible" so as to win over as many voters as possible. Boulding (1966: 484) names this phenomenon "[t]he Principal of Minimum Differentiation."
} 
loses the election after obtaining less than $50 \%$ of the vote. ${ }^{6}$

Figure 2.1: Two-candidate election with defection

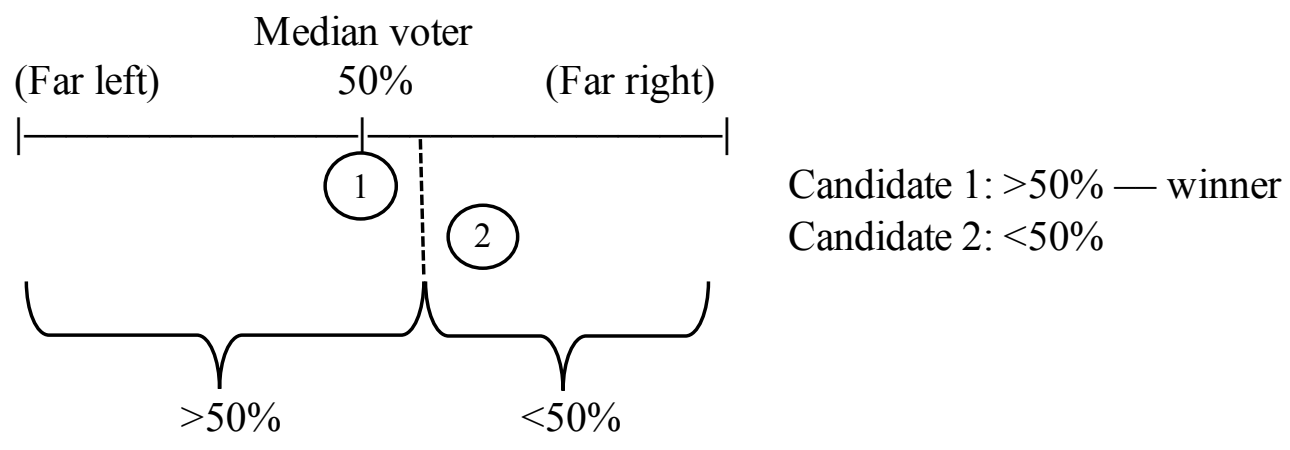

In contrast to one candidate defecting, Figure 2.2 illustrates the case when both candidates locate themselves at the ideological position of the median voter, per Downs' (1957) argument. In such a case, voters cannot distinguish between policy platforms of the two candidates, and as such, each candidate ends up with $50 \%$ of the vote. The election is essentially determined by a coin flip. ${ }^{7}$ When there are more than two-candidates in a race, however, Cox (1987) argues that the incentive is not to adopt the ideological position of the median voter, but rather to defect, as defecting likely maximizes one's vote share. ${ }^{8}$ For instance, in Figure 2.3, all three candidates locate themselves at the ideological position of the median voter, and all three candidates end up with with the same vote share. Again, the victor of such an election would be determined randomly.

\footnotetext{
${ }^{6}$ Similar to Hotelling's (1929) scenario where customers are assumed to be evenly distributed, Downs (1957) assumes that voters are uniformly distributed along the political spectrum.

${ }^{7}$ Indeed, many such elections are literally determined by a coin flip, and perhaps even more should be (see Pitts 2006; Triossi 2013).

${ }^{8}$ Similarly, Osborne (1995: 284) argues that "when there are more than two (potential) candidates, then the basic incentive [for minimum differentiation] inherent in the Hotelling model is significantly diluted." Instead, the incentive is for candidates to disperse along the ideological spectrum.
} 
Figure 2.2: Two-candidate election without defection

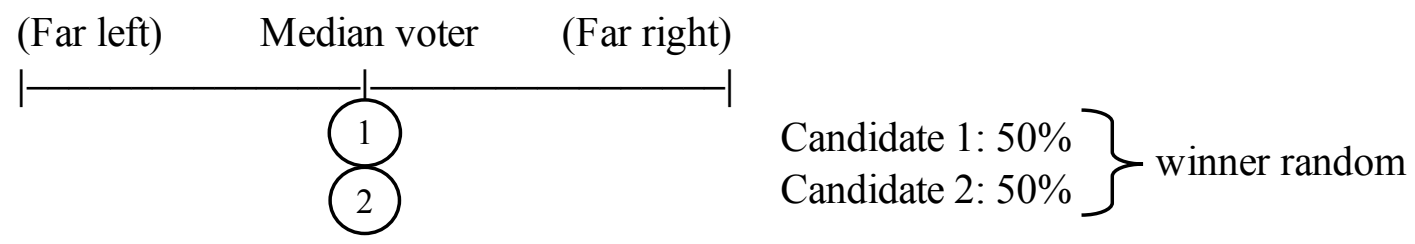

Figure 2.3: Three-candidate election without defection

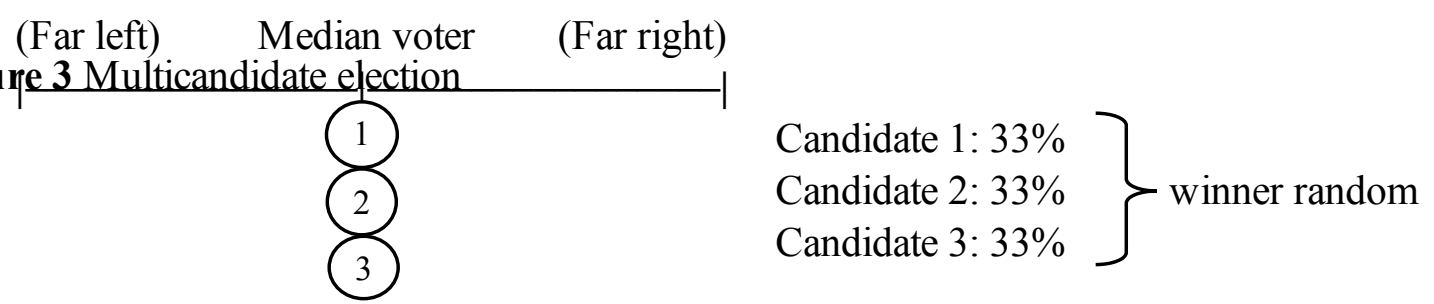

Figure 2.4 illustrates the scenario of a three-candidate race with defection. In this case, Candidate 3 (the defector) ends up with just under 50\% of the vote. Candidate 1 and 2 together gather the remaining votes, but their total is split between both candidates (since both candidates have identical policy platforms that cannot be differentiated by voters). In the end, Candidate 3 likely wins the elections with just under $50 \%$ of the vote, while Candidate 1 and 2 both lose the election with each getting just over $25 \%$ of the vote (i.e. they each net half of all the votes that were not obtained by Candidate 3).

Figure 2.4: Three-candidate election with defection

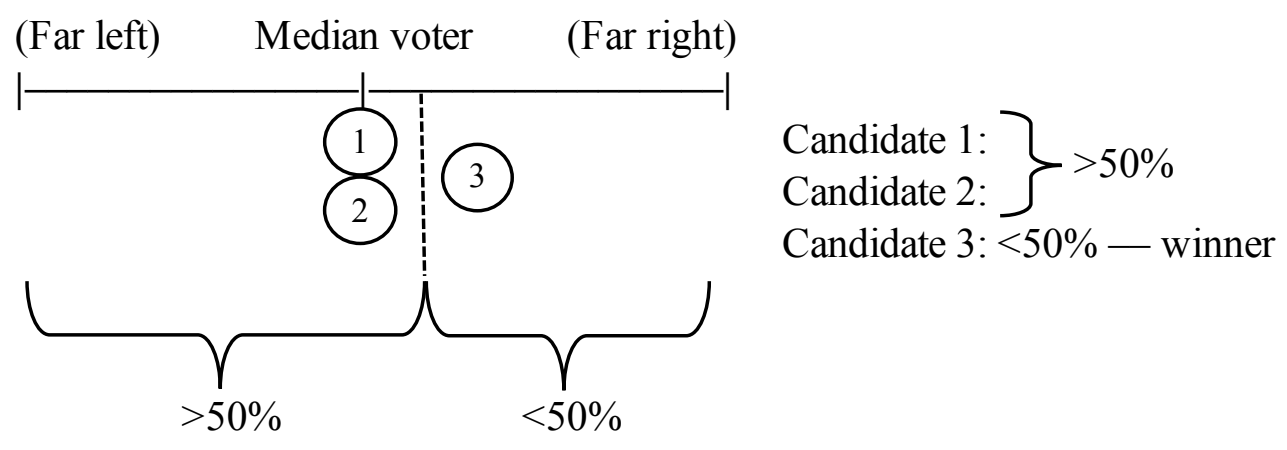


Figure 2.5: Three-candidate election with defection and runoff

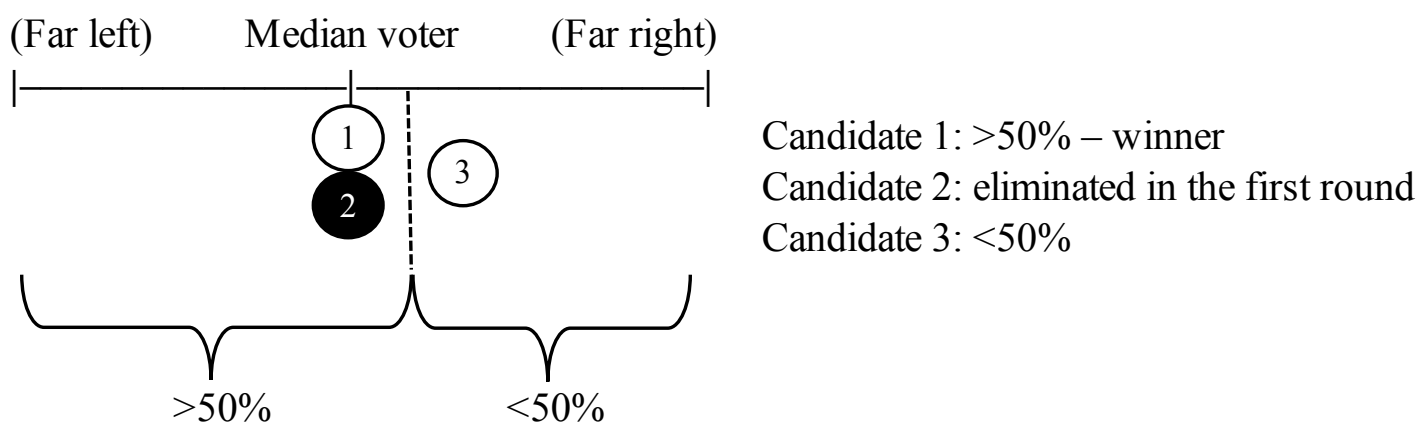

Haan and Vokerink (2001) adds nuance to Cox's (1987) model by accounting for the possibility of a two-candidate runoff following a multi-candidate election. They argue that while defecting from the ideological position of the median voter may increase the likelihood that a candidate wins the first round, "[i]n the runoff round, however, he [or she] will be beaten by one of the candidates that did choose the median voter's position" (Haan and Vokerink 2001: 160). ${ }^{9}$ In other words, "the runoff system... induces policy moderation" (Bordignon, Nannicini, and Tabellini (2016: 2350-2351); with Figure 2.5, I illustrate this concept. Similar to Figure 2.4 (i.e. a three-candidate election with defection), Candidate 3 in Figure 2.5 nets the greatest number of votes (i.e. just under 50\%), while the Candidate 1 and 2 collectively obtain (and subsequently split) the remaining votes. ${ }^{10}$ Under a runoff rule, however, the two candidates with the greatest number of the votes advance to a runoff round. Candidate 3 (i.e. the candidate with the most votes) therefore

\footnotetext{
${ }^{9}$ Emphasis added. Note that in their formal model, Haan and Volkerink (2001: 157) "show that the principle of minimum differentiation holds in two-round elections, for any number of candidates, regardless of the presence of entrants." In a follow-up paper, however, Matsushima (2007: 1185) "show[s] that the principle of minimum differentiation may not hold, when uncertainty of the position of the median voter is introduced."

${ }^{10} \mathrm{Keep}$ in mind that the purpose of Figures 2.1 and 2.2 is to visually illustrate the argument of Hotelling (1929) and Downs (1957). The purpose of Figures 2.3 and 2.4 is to visually illustrate the argument of Cox (1987) and Osborne (1995). Finally the purpose of Figures 2.4 and 2.5 is to visually illustrate the argument of Haan and Vokerink (2001). Note that the intent of this section is not to solve a formal model, but rather to review (and illustrate) the formal literature in the process of constructing my theoretical argument.
} 
advances, while either Candidate 1 or 2 also advances. Since Candidate 1 and 2 both have indistinguishable policy platforms, both likely get the same number of votes, and the one to advance to the runoff round (e.g. Candidate 1 in my example), is effectively determined randomly. In the runoff round, voters again chose the candidate to which they are ideologically closest. Similar to a two-candidate race with defection (see Figure 2.1), the runoff round favors the candidate closest to the ideological position of the median voter. ${ }^{11}$ This leads me to my first premise:

P1: In comparison to when the president is elected without a runoff rule, when the president is elected using a runoff rule, there is likely a reduced distance between the president and the median voter.

\subsubsection{A reduced percent of the cabinet in the same party as the pres-}

\section{ident}

In his seminal critique of presidential systems, Linz (1990: 56) argues that "[p]residentialism

is ineluctably problematic because it operates according to the rule of 'winner-take-all'an arrangement that tends to make democratic politics a zero-sum game."12 In contrast,

\footnotetext{
${ }^{11}$ Note that when there are more than three candidates, Brusco, Dziubiński, and Roy (2012: 447) "show that Nash equilibria in pure strategies always exist and that there are typically multiple equilibria, both convergent (all candidates are located at the median) and divergent (candidates locate at distinct positions)." In a follow-up paper, Xefteris (2014: 619) adds that "when the number of competing candidates is odd the only equilibrium guaranteed to exist for any distribution is the convergent one, and when the number of competing candidates is even both divergent and convergent equilibria always exist." As such, while a Nash equilibrium always exists at the median voter when the there are three or more candidate competing under a runoff rule—as Haan and Vokerink (2001) predict—multiple Nash equilibria also exist when their are an even number of candidates and "half of the candidates locate at a certain point to the left of the median voter and the other half locate (equidistantly) to the right of the median voter" (Xefteris 2014: 619).

${ }^{12}$ Note that "Westminster, the Mother of Parliaments... produces such outcomes as often as any presidential system does" (Horowitz 1990: 79).
} 
Linz (1990: 52) touts "that the superior historical performance of parliamentary democracies." In a rebuttal, Horowitz (1990:79) acknowledges that Linz "is right to worry about winner-take-all outcomes and their exclusionary consequences." However, he suggests that Linz's anti-presidentialism "thesis boils down to an argument not against the presidency, but against plurality election, not in favor of parliamentary systems but in favor of parliamentary coalitions" (Horowitz 1990: 79). ${ }^{13}$

As Laver and Schofield (1998: 7) note, "[c]oalition government is an area of political activity which has been both the object of careful empirical analyses and the foundation for an elaborate superstructure of theory." However, while "[t]here are mountains of works on cabinet formation in parliamentary regimes... only recently has cabinet formation in presidential systems begun to receive detailed attention" (Neto 2006: 417). ${ }^{14}$ Today, many comparativists now recognize "that coalitional presidentialism is quite common around the world," and as such, "[t]he literature has now moved beyond establishing that presidents govern with coalitions to asking how presidents govern with coalitions" (Chaisty, Cheesman, and Power 2018: 18). ${ }^{15}$

According to Freudenreich (2016: 82), “[r]ecent research suggests... that governability in presidential systems is better than Juan Linz and others expected, and connects these successes with the ability of presidents to form and manage cabinet coalitions." Cheibub (2007: 50) argues that "[t]here is a range of possible scenarios in presidential systems where presidents will make coalition offers and parties will find it in their interest

\footnotetext{
${ }^{13}$ Emphasis in original.

${ }^{14}$ For an overview of this literature, see the following: Altman (2000); Neto (2002); Cheibub (2002); Negretto (2006); Kang (2009); Alemán and Tsebelis (2011); Raile, Pereira, and Power (2011); Shin (2013); Camerlo and Pérez-Liñán (2015); Chaisty and Chernykh (2017); Lee (2018a, 2018b); Chaisty and Power (2019).

${ }^{15}$ Emphasis in original.
} 
to accept them." The conventional view, for instance, has attributed cabinet composition in presidential systems to institutional characteristics, such as electoral rules, formal powers of the president, and party characteristics. ${ }^{16}$ Freudenreich (2016: 80), however, "argues that the partisan composition of cabinets is largely predetermined by the bargaining and the competition before and during presidential elections." He asserts that "pre-electoral coalitions...give parties with weak blackmailing power in the law-making process the chance to team up with presidential candidates and thereby secure a share of cabinet posts after the election" (Freudenreich 2016: 80-81).

According to Riker (1962: 33), candidates want to "create coalitions just as large as they believe will ensure winning and no larger." This is because the more power a candidate negotiates away during pre-electoral bargaining, the less power they will retain after the election. When a president wins a single-round election under plurality rule, it is possible that the only 'coalition' is his or her own political party. As such, it would make sense that the president would fill important roles, such as those in the cabinet, entirely with loyal partisans. However, with a presidential election that uses a runoff rule, candidates are incentivized to build a coalition that they believe will be big enough to win to the second round. Indeed, Linz (1990: 57-58) seems to acknowledge this point, as he concedes that a "two-round election can... reproduce something like the negotiations that 'form a government' in parliamentary regimes." He explains that "run-off provisions... set up a confrontation between the two major candidates," and as a result, "broad coalitions are likely to be formed... in preelection maneuvering" (Linz 1990: 57).

In Table 2.1, I present the results from the 2007 presidential election in East

${ }^{16}$ See, for example, the following: Cheibub, Przeworski, and Saiegh (2004); Neto (2006); Martínez-Gallardo and Schleiter (2015). 
Timor, which illustrates how a runoff rule can encourage such maneuvering. Assuming no changes in each candidates' vote share, had this election occurred under plurality rule, Francisco Guterres would have won with nearly $28 \%$ of the vote. ${ }^{17}$ Instead, however, one month after that first round, Guterres and Ramos-Horta advanced to a second round. As you can see in Table 2.1, from the first round to the second, Guterres was only able to increase his vote share by a small amount. Ramos-Horta, however, more than tripled his vote share after getting several other candidates to endorse him, three of whom subsequently were appointed to positions within his new government (while the fourth was able to extract a major policy concession). While there was no guarantee that the endorsements would directly lead to votes (as those whose preferred candidate was eliminated could have opted to have abstained from voting in the runoff round), "what appeared to happen was the support by a majority of parties for Ramos-Horta translated into their supporters coming out in numbers that were consistent with Round One” (Kingsbury 2009: 180).

Table 2.1: The 2007 Presidential election in East Timor

\begin{tabular}{lccl}
\hline \multirow{2}{*}{ Candidates } & \multicolumn{2}{c}{ Percent of the vote } & \multirow{2}{*}{ Post election } \\
\cline { 2 - 3 } & 1st round & 2nd round & \\
\hline Francisco Guterres & 27.89 & 30.82 & \\
José Ramos-Horta & 21.81 & 69.18 & Becomes president \\
Fernando de Araújo & 19.18 & & Dialogue with rebels initiated \\
Francisco Xavier do Amaral & 14.39 & \\
Lúcia Lobato & 8.86 & Appointed as Minister of Justice \\
Manuel Tilman & 4.09 & & \\
Avelino Coelho da Silva & 2.06 & Appointed as Secretary of State for Energy Politics \\
João Viegas Carrascalão & 1.72 & Appointed as Vice-Minister of Infrastructure \\
\hline
\end{tabular}

According to Kingsbury (2009: 182), after the election, there were "questions about the capacity of some cabinet ministers... appointed not for competence but as polit-

\footnotetext{
${ }^{17}$ Such results are not unheard of, and indeed several candidates have won the presidency with even less support. For instance, Fidel V. Ramos won the 1992 Philippine presidential election with just over 23\% of the vote.
} 
ical reward." This phenomenon of bartering cabinet-level positions for endorsements during pre-runoff maneuvering is not simply a feature of patronage-prone newly-democratized states, such as East Timor; it can also be observed in advanced industrialized democracies, such as France. ${ }^{18}$ For example, shortly after after securing roughly $24 \%$ in the first round of France's 2017 president election, Emmanuel Macron sought to broaden his reach by appealing to voters of the parties that were eliminated in the first round. In the runoff, Macron's support jumped to $66 \%$. Among the ministers appointed to roles within his new government, three were affiliated with Les Républicains (LR), two came from Parti socialiste (PS), another two came from Parti radical de gauche (PRG), and finally the leader of Mouvement démocrate (MoDem) also secured a position. In total, of the 18 ministers in Macron's newly-appointed cabinet, only two came from Macron's own political party. In both East Timor and France, instead of one individual and one party dominating the new administration, a runoff rule lead to pre-runoff-round bargaining, which ended up producing a government where several cabinet ministers were not in the same party as the president. This leads me to my second premise:

P2: In comparison to when the president is elected without a runoff rule, when the president is elected using a runoff rule, there is likely a reduced percentage of cabinet members in the same party as the president.

\footnotetext{
${ }^{18}$ To augment my Asian example (East Timor) and European example (France), I have a third example, this time from South America. After the first round of the 2010 Colombian presidential election, Germán Vargas Lleras of Cambio Radical (CR) came in third place behind Juan Manuel Santos of Partido Social de Unidad Nacional (Party of U). Prior to the runoff round, Lleras threw him support behind Santos, and after the election, a victorious Santos ended up appointing Lleras as his justice minister.
} 


\subsubsection{A reduced likelihood that the president is elected without a ma- jority}

Typically, in states that have a runoff rule, if no one candidate receives more than $50 \%$ of the vote in the first round, then the top two finishers advance to a runoff election. Notably, however, there are a few exceptions to this. For instance, in Costa Rica, a candidate with $40 \%$ of the vote can avoid a runoff. In Argentina, a candidate with $45 \%$ of the vote can avoid a runoff, or they can also avoid a runoff by netting $40 \%$ of the vote and have at least a $10 \%$ lead over the second-place candidate. Finally, in Nicaragua, up until recently, a candidate with $40 \%$ of the vote could have avoided a runoff, or they could also have avoided a runoff by netting $35 \%$ of the vote and having at least a $5 \%$ lead over the second-place candidate.

While it is possible that a single-round presidential election under plurality rule could produce a president with more than $50 \%$ of the vote, obtaining a majority of the vote gets increasingly difficult as more candidates enter the race. In contrast, a presidential election under a runoff rule nearly always produces a president with more than $50 \%$ of the vote, as in most cases, if no one candidate obtains $50 \%$ of the vote in the first round, then a subsequent runoff round ensures that at least one candidate reaches a majority. This leads me to my third premise:

P3: In comparison to when the president is elected without a runoff rule, when the president is elected using a runoff rule, there is a reduced likelihood that the president is elected without a majority. 


\subsection{Determinants of government respect for human rights}

To review, in the preceding section I propose three premises which collectively argue that the presence of a runoff rule reduces the following: the distance between the president and the median voter (i.e. P1), the percentage of cabinet members in the same party as the president (i.e. P2), and finally the likelihood that the president is elected without a majority (i.e. P3). In this section, I will introduce three additional premises, which collectively detail how each of the outcomes above are negatively associated with high government respect for human rights.

\subsubsection{The downside of a large distance between the ideological posi- tion of the president and the median voter}

In his early work on constitutions, Bryce (1901: 96-7) suggests that "in politics, we may call the tendency which draws men [and women] or groups of men [and women] together... a Centripetal force, and that which makes men [and women], or groups, break away and disperse, a Centrifugal [force]." Nearly a century later, Cox (1990: 927) expands upon Bryce's typology by proposing "a crude division of electoral systems into those dominated by centripetal incentives and those dominated by centrifugal incentives." He argues that "[c]entripetal incentives lead political parties (or candidates) to advocate centrist policies," while "centrifugal incentives... lead to the advocacy of more or less extreme positions" (Cox 1990: 903). Reilly (2002: 159) adds that a "centripetal political system... is designed to focus competition at the moderate center rather than the extremes by making politicians do more than just shop for votes in their own community." Instead of accentuating differences, "[c]entripetal [political systems] encourage a search for com- 
mon ground" (Gerring, Thacker, and Mereno 2005: 569). As detailed in the preceding section, a runoff rule favors candidates that adopt the ideological position of the median voter (Haan and Vokerink 2001; Brusco, Dziubiński, and Roy 2012); as such, a presidential runoff rule would be an example of a centripetal political system.

Gerring, Thacker, and Moreno (2005: 569) argue that "[c]entripetal, rather than centrifugal, [political systems] create the conditions for good governance." Indeed Gerring and Thacker (2008: 156) find "strong correlations between centripetal [political systems] and measures of good governance." According to Weiss (2000: 801), "good governance is more than multiparty elections, a judiciary and a parliament, which have been emphasized as the primary symbols of Western-style democracy." Instead, Weiss (2000: 801) sees "good governance" as the "protection of human rights." While "[c]entripetalism is associated with more bureaucratic quality, higher tax revenues, better investment ratings, more trade openness, greater economic prosperity, fewer infant deaths, longer life expectancy, and lower rates of illiteracy, all else being equal" (Gerring, Thacker, and Moreno 2005: 576), it seems self-evident that centripetalism should also be associated with greater government respect for human rights as a clear manifestation of good governance would be high government respect for human rights.

In sum, the literature suggests the following three relationships (which are illustrated in Figure 2.6): first, centripetal political systems (such as states that elect their president using a runoff rule) are likely to be positively associated with good governance (a manifestation of which is high government respect for human rights); second, as previously described with $\mathbf{P 1}$, states that elect their president using a runoff rule are likely to be negatively associated with the distance between the president and the median voter; finally, 
Figure 2.6: The relationship between centripetal political systems, the president's distance from the median voter, and good governance.

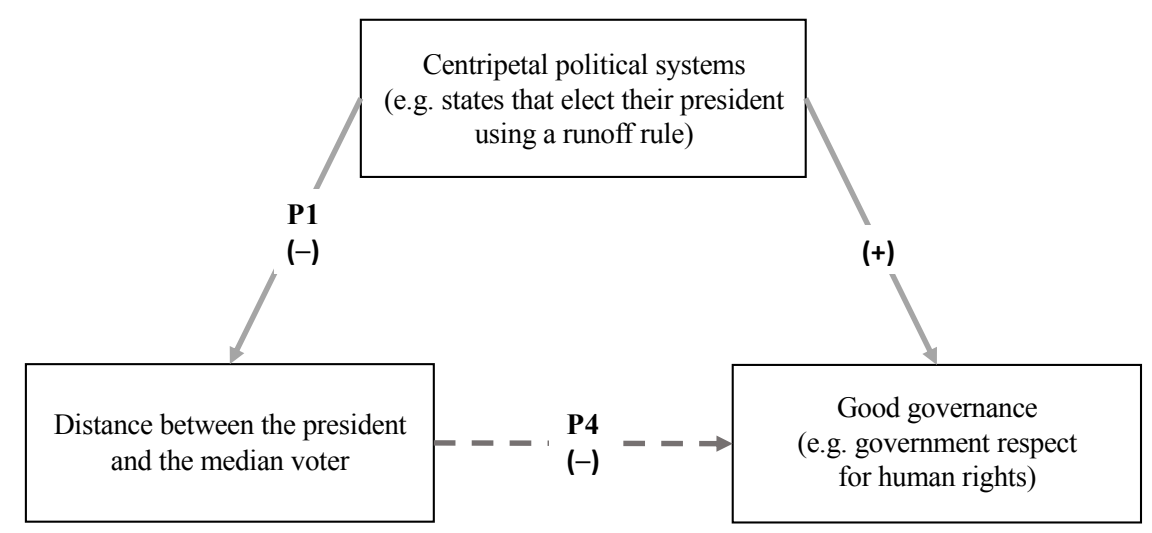

given the first two relationships, it is likely that the distance between the president and the median voter is also negatively associated with high government respect for human rights. This leads me to my fourth premise:

P4: In comparison to when there is a small distance between the president and the median voter, when there is a large distance between the president and the median voter, that state is less likely to be associated with high government respect for human rights.

\subsubsection{The downside of cabinets comprised of a high percent of mem- bers in the same party as the president}

Tsebelis (2002) argues that all along the path of potential policy change, there are points where a proposal can be delayed or overridden by 'veto players.' With regards to human rights, Davenport (2007: 119) notes that "those governments with fewer Veto Players have fewer restrictions on the leader and thus are less constrained in behavior that leads to repression; those governments with larger numbers of Veto Players have greater 
restrictions on political authorities and are therefore more constrained in what they can and cannot do." He adds that when "the repressive process [is] subject to Veto, then decision makers... hesitate to engage in the relevant behavior" because " "transaction costs" are increased by discussion, negotiation, compromise, and side payments" (Davenport 2007: 57). In other words, the introduction of veto players promotes government respect for human rights by making it costly to adopt repressive policies.

According to Haggard, McCubbins, and Shugart (2001: 320), veto players can take "the form of... more parties in a coalition." One area likely influenced by any such 'coalition' would be the cabinet, which is comprised of the heads of each executive ministry. ${ }^{19}$ One such ministry is the ministry of justice, which is headed by the justice minister. ${ }^{20}$ In most presidential systems, the ministry of justice is in charge of the administration of justice. As head of this ministry, the justice minister is typically responsible for organizing the justice system, maintaining the legal system and public order, as well as overseeing the national police and national prison system. It has been said that "the operation of the criminal justice system is situated at a central point of the relationship between the [s]tate and the citizens, indeed one could say... that it is the most precise barometer of respect for and the effective observance of the fundamental rights of persons" (Paz y Paz 2016: 30). Unfortunately, however, being at the central point 'between the state and its citizens' also means that the operation of the criminal justice system is exceptionally well-positioned to be conduit for the state to take advantage of the rights of its citizens. As head of the operation of the criminal justice system, the justice minister is uniquely situated to be either a guardian of rights or an overseer of abuse.

\footnotetext{
${ }^{19}$ In some states, 'ministries' are referred to as 'departments.'

${ }^{20}$ In some states, the minister of justice is called the minister for justice, the secretary of justice, or the attorney general.
} 
If a president were to propose a new policy (or renewal of a current policy) that the justice minister were to disagree with (such as a ratcheting up of repression), the justice minister could attempt to exercise an effective veto of the president's preferred policy in numerous ways, such as by privately (or publicly) threatening to withdraw their support of the president's overall agenda and/or attempting to exercise autonomy over how (or whether) the president's policy is implemented and enforced within their ministry. The president (if even aware of the insubordination) would then be in the awkward position of having to fire the relevant minister/ask for their resignation (both of which bring a political cost) or keep the relevant minister and simply give up on said policy. ${ }^{21}$ If a president and his or her justice minister are from the same political party, one could reasonably expect their interests to align. ${ }^{22}$ However, if the president agreed to nominate someone from a different party as a result of a bargaining process, then one would expect that the interests of the president and the justice minister to be less likely to align. This is because ministers are constantly "trying to move government policy outputs as close as possible to their own preferred policies" (Laver and Shepsle 1990: 874). In such situations when the justice minister is not in the same party as the president, one would expect he or she to be more willing and/or empowered to neutralize any of the president's more unsavory policies as "[i]t is very difficult to implement policy in the face of active opposition from the relevant minister" (Laver and Shepsle 1990: 874).

\footnotetext{
${ }^{21}$ For an extreme example of the high cost for firing ministers, see Slater (2004). In the case of Indonesia, dismissing ministers ultimately led to the impeachment (and subsequent removal from office) of President Abdurrahman Wahid.

${ }^{22}$ Samuels and Sugart (2010: 255) note that in presidential systems, "the separation of powers creates presidentialized parties." Presidents "often engineer a de facto reversal of the party-executive principal-agent relationship" found in parliamentary systems, and as such, presidents "come to control parties for their own purposes" (Samuels and Sugart 2010: 251). They note that even "[p]olitics in most semi-presidential systems is highly presidentialized" (Samuels and Shugart 2010: 256).
} 
Up to this point I have focused my discussion on the capacity of the justice minster to help facilitate (and/or stymie) the president's desire to repress. I would like to note that this cabinet ministry is by no means the only ministry capable of overseeing (and/or undermining) repressive policies. For instance, both the defense and interior (i.e. home affairs) ministers also wield considerable influence, among many others. As such, I contend that a state's danger to human rights is related to the percent of the entire cabinet that is beholden to the president (i.e. in the same political party). ${ }^{23}$

Figure 2.7: The relationship between pre-election bargaining, the percent of the cabinet in the same party as the president, and the introduction of veto players.

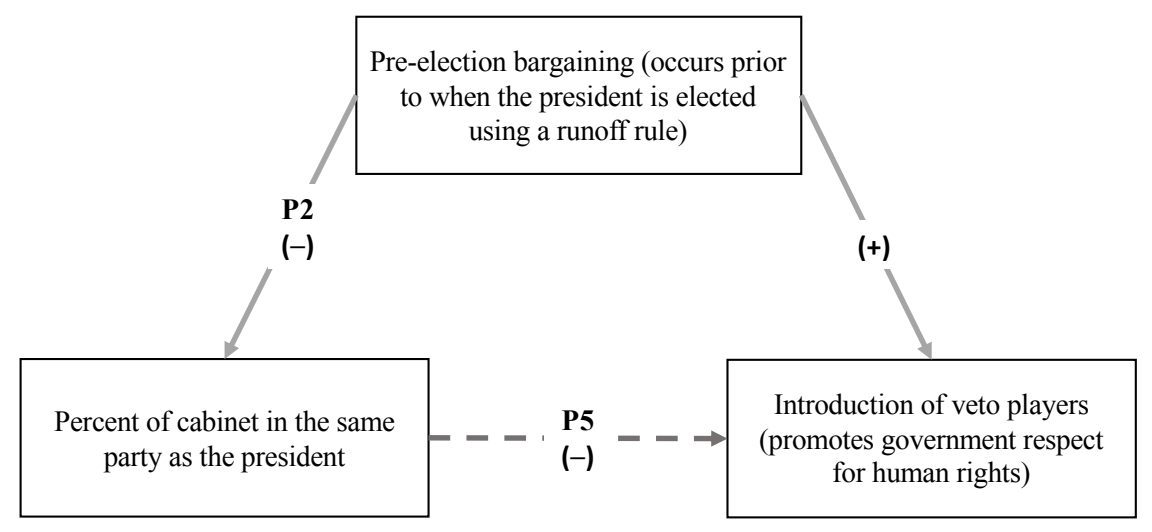

In sum, the literature suggests the following three relationships (which are illustrated in Figure 2.7): first, pre-election bargaining (which is encouraged by a runoff rule) is likely to be positively associated with the introduction of veto players into the president's cabinet (which promotes government respect for human rights as additional veto players make the adoption of repressive policies more costly); second, as previously described with P2, states that elect their president using a runoff rule are likely to be negatively associated with the percent of the cabinet in the same party as the president (as the president

${ }^{23}$ An alternate argument would that it is actually not the entire cabinet that matters, but rather those ministries with the greatest capacity to repress, such a ministry of justice. I address this in the Appendix. 
negotiates away control of cabinet ministries during pre-election bargaining); finally, given the first two relationships, it is likely that the percent of the cabinet in the same party as the president is also negatively associated with high government respect for human rights. This leads me to my fifth premise:

P5: In comparison to when the cabinet is comprised of a small percentage of members in the same party as the president, when the cabinet is comprised of a large percentage of members in the same party as the president, that state is less likely to be associated with high government respect for human rights.

\subsubsection{The downside of presidents elected without a majority}

Bueno de Mesquita et al. (2003) argue that two factors determine how a state's chief executive is chosen: the 'selectorate' and the 'winning coalition.' The 'selectorate' refers to the proportion of a state's adult population that has a formal role in selecting the chief executive. The 'winning coalition' refers to the minimum proportion of the selectorate whose support is needed for the chief executive to obtain power. In systems where the president is elected directly, the selectorate is simply all voting-eligible adults. The winning coalition, however, changes depending upon whether or not the election has the potential to advance to a runoff round. For most elections with a runoff rule, the minimum winning coalition is obtaining at least a majority (and if this does not happen in the first round, a second round is required). ${ }^{24}$ For elections that do not have a runoff rule, however,

\footnotetext{
${ }^{24}$ As mentioned in the preceding section, while most states that use a runoff rule require that at least one candidate obtain at least $50 \%$ of the vote, in some states this is not the case. For instance, in Costa Rica, a candidate with $40 \%$ of the vote can avoid a runoff. In Argentina, a candidate with $45 \%$ of the vote can avoid a runoff, or they can also avoid a runoff by netting $40 \%$ of the vote and have at least a $10 \%$ lead over the second-place candidate. Finally, in Nicaragua, a candidate with $40 \%$ of the vote can avoid a runoff, or they can also avoid a runoff by netting $35 \%$ of the vote and have at least a $5 \%$ lead over the second-place
} 
the minimum winning coalition is a plurality (i.e. simply obtaining more votes than any other candidate), which does not require a majority.

Bueno de Mesquita et al. (2003) argue that when a winning coalition is small, it is more efficient for the chief executive to depend upon the use of private goods to earn (and maintain) the support and loyalty of the winning coalition. However, when the winning coalition is large, it is prohibitively expensive to provide private goods to every individual member of the chief executive's winning coalition. In such cases, public goods are used to try and win over (and later satisfy) the winning coalition. Incidentally, public goods benefit the public at large, including those not even in the chief executives winning coalition. ${ }^{25}$

Recently, human rights scholars have begun arguing that government respect for human rights could (and should) be viewed as a public good (Augenstein 2016; Walker 2016). Returning to Bueno de Mesquita et al. (2003: 351), they find that "[r]espect for human rights is common in systems with large winning coalitions," while "oppression of political opponents is common in systems with small winning coalitions." ${ }^{26}$ In essence, they already treat government respect for human rights as a public good and targeted oppression as a private good when extending their argument that larger winning coalitions are more apt to provide public goods, while smaller winning coalitions are more apt to providing private goods.

In sum, the literature suggests the following three relationships (which are illuscandidate.

${ }^{25}$ See Shugart (1999) for an earlier work examining the provision of public goods. Note, however, that he does not differentiate between those presidential systems with a runoff rule, and those without.

${ }^{26}$ Horowitz (1990:73) adds that "a directly elected president may think he has a popular 'mandate,' even if he has been elected with only a small plurality of the vote, perhaps even less than 40 percent," however, in such cases when a president is elected with such a low level of support, "[t]he potential for conflict is accordingly enhanced." 
Figure 2.8: The relationship between a large minimum winning coalition, presidents elected without a majority, and the provision of public goods.

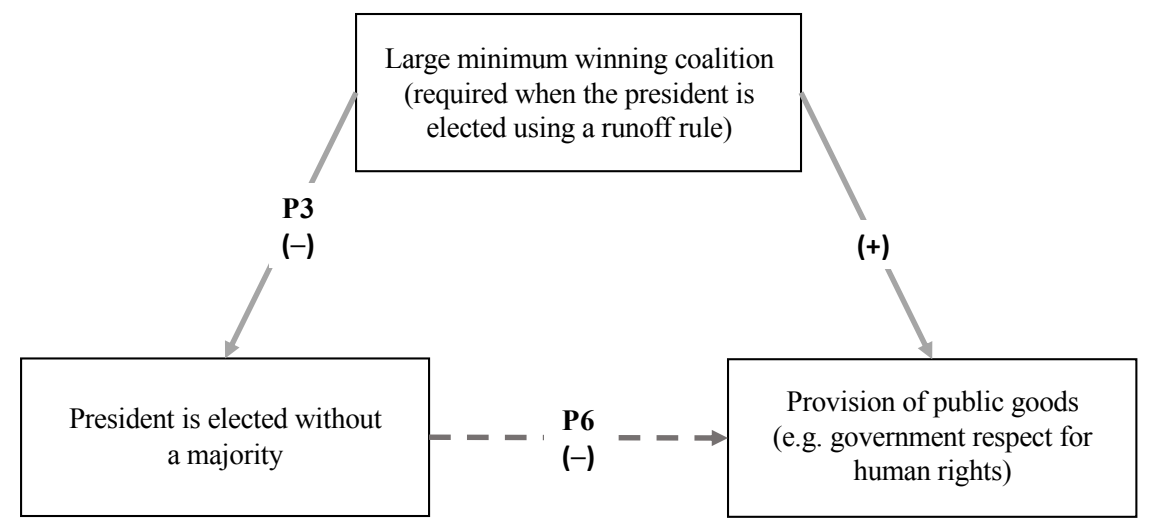

trated in Figure 2.8): first, building a large winning coalition (as is required when states elect their president using a runoff rule) is likely to be positively associated with the provision of public goods (an example of which would be government respect for human rights); second, as previously described with $\mathbf{P 3}$, presidents elected using a runoff rule are likely to be negatively associated with winning that election without a majority; finally, given the first two relationships, it is likely that presidents elected without a majority are also negatively associated with high government respect for human rights. This leads me to my sixth premise: 
P6: In comparison to when the president is elected with a majority, when the president is elected without a majority, that state is less likely to be associated with high government respect for human rights.

\subsection{Presidents elected using a runoff rule}

In Figure 2.9, I review my theoretical argument. In essence, with P1, P2, and P3, I argue that the presence of a runoff rule leads to the following three outcomes: a reduced distance between the president and the median voter, a reduced percentage of cabinet members in the same party as the president, and finally a reduced likelihood that the president is elected without a majority. Furthermore, with P4, P5, and P6, I argue that each of the three outcomes above are negatively associated with high government respect for human rights. If the presence of a runoff rule reduces outcomes that in turn are negatively associated with high government respect for human rights, then a runoff rule should be positively associated with high government respect for human rights. This leads me to my hypothesis:

In comparison to when the president is elected without a runoff rule, when the president is elected using a runoff rule, that state is more likely to be associated with high government respect for human rights.

To wrap up, Davenport and Armstrong (2004: 551) argue that "the adoption of some democratic elements will not automatically decrease repressive activity." On the contrary, perhaps it actually is possible to decrease repressive activity by simply adopting certain elements. I argue that in order to promote government respect for human rights, 
constitutional designers should embrace a presidential runoff rule, as a presidential runoff rule should be positively associated with high government respect for human rights because it reduces determinants that are in turn negatively associated with high government respect for human rights. In the next chapter, I will detail how I test this hypothesis (as well as my six premises).

Figure 2.9: The relationship between presidents elected using a runoff rule and government respect for human rights.

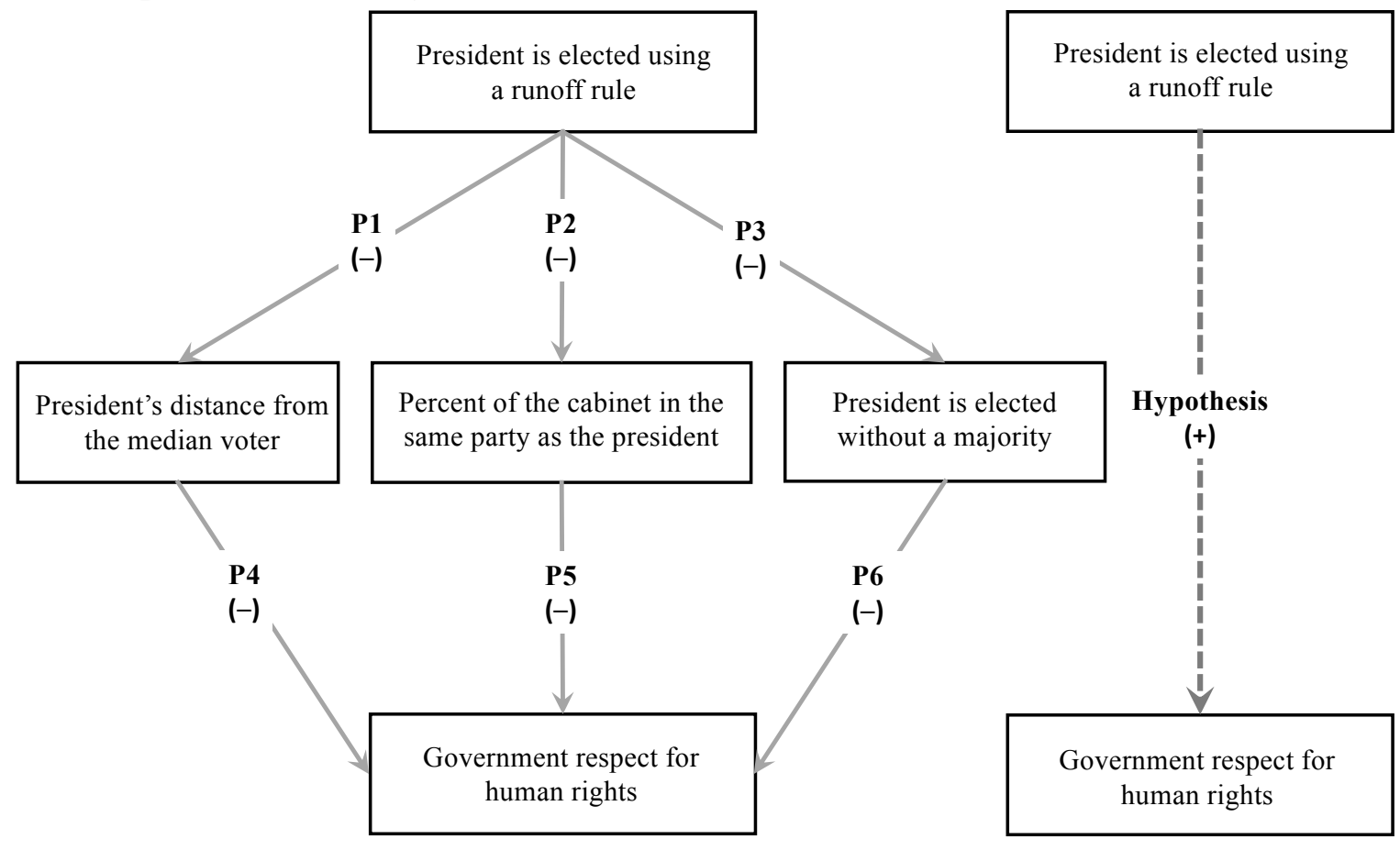




\section{Chapter 3}

\section{Research Design}


In this chapter I begin with a discussion of my sample. I then detail how I measure the dependent variable of my hypothesis (i.e. government respect for human rights). Next, I discuss how I have constructed each of the variables necessary to test my six premises. Finally, I discuss several theoretically-relevant control variables, and present some summary statistics.

\subsection{Sample}

In order to determine my sample, I consulted Bormann and Golder's (2013: 2) Democratic Electoral Systems Around the World dataset, which "focus[es] on nationallevel (lower house) legislative and presidential elections in democratic regimes." Following Cheibub, Gandhi, and Vreeland's (2010) democracy versus dictatorship typology, Bormann and Golder's (2013: 13) dataset considers a regime to be 'democratic' if “(i) the chief executive is elected, (ii) the legislature is elected, (iii) there is more than one party competing in elections, and (iv) an alternation under identical electoral rules has taken place." All 'democracies' fall into one of three subtypes: parliamentary, presidential, and semi-presidential. For my study, I drop all parliamentary systems. Additionally, I drop all systems where the president is not directly elected.

\subsection{Dependent variable}

Within the human rights literature, there are two primary indicators for measuring human rights. The most commonly used measure is the Cingranelli-Richards Human Rights Dataset's Physical Integrity Rights Index (CIRI). The second most commonly used 
measure is the Political Terror Scale (PTS), which—like CIRI—is coded using data from the US Department of State's Country Reports on Human Rights Practices and Amnesty International's Annual Report (Gibney et al. 2015). As you can see in Table 3.1, CIRI is an "additive index created from four individual indicators (torture, extrajudicial killing, political imprisonment, disappearance) and ranging from 0 (no respect for any of these four rights) to 8 (full respect for these four rights)" (Cingranelli and Richards 2010: 413). Per the the coding manual, each of the four constituent indicators are individually scored on a scale from ' 0 ' to ' 2 ' where ' 0 ' denotes 50 or more violations, ' 1 ' denotes 1 to 49 violations, and '2' denotes no violations (Cingranelli, Richards, and Clay 2014).

Table 3.1: Comparing CIRI versus PTS coding.

\begin{tabular}{l|l}
\hline $\begin{array}{l}\text { Cingranelli-Richards Physical Integrity } \\
\text { Rights Index (CIRI) }\end{array}$ & The Political Terror Scale (PTS) \\
\hline $\begin{array}{l}\text { Score is determined by individually } \\
\text { evaluating indicators of repressive practices } \\
\text { for torture, summary execution, } \\
\text { disappearance, and political imprisonment. }\end{array}$ & $\begin{array}{l}\text { Score is determined by collectively evaluating } \\
\text { the range of the population effected by } \\
\text { instances of torture, summary execution, } \\
\text { disappearance, and political imprisonment. }\end{array}$ \\
\hline $\begin{array}{l}\text { The overall score is determined by adding } \\
\text { together all four constituent indicators of } \\
\text { repressive practices, each of which is based } \\
\text { on the following coding scheme: }\end{array}$ & $\begin{array}{l}\text { The overall score is based on the following } \\
\text { coding scheme: }\end{array}$ \\
$\begin{array}{l}1=\text { zero violations } \\
1=1 \text { to } 49 \text { violations }\end{array}$ & $\begin{array}{l}1=\text { repression extremely rare } \\
2=\text { repression is limited } \\
3=50 \text { or more violations }\end{array}$ \\
$4=$ repression is common expanded to larger numbers \\
\end{tabular}

While CIRI scores are determined by individually evaluating instances of torture, summary execution, disappearance, and political imprisonment (then adding together all four constituent scores), PTS scores are determined by collectively evaluating the range 
of the population effected by instances of torture, summary execution, disappearance, and political imprisonment. States are designated a level ranging from ' 1 ' to '5', with ' 1 ' indicating that the state is under a secure rule of law, people are not imprisoned for their views, torture is rare or exceptional, and political murders are extremely rare. A designation of ' 2 ' indicates that there is a limited amount of imprisonment for nonviolent political activity, torture is exceptional, and political murder is rare. A designation of ' 3 ' indicates that there is extensive political imprisonment, and political murders are common. A designation of ' 4 ' indicates that disappearances, torture, and political murders are all common; however, state terror only affects those who interest themselves in politics. Finally the scale tops out at ' 5 ', which indicates that state-sanctioned repression has been extended to the whole population, and state leaders place no limits on the means or thoroughness with which they pursue personal or ideological goals (Wood and Gibney 2010). While CIRI seeks to measure "actual government practices" (Cingranelli and Richards 2010: 406), PTS aims to measure "the 'range' of violence committed... in short, what segments of the population are targeted" (Wood and Gibney 2010: 368).

Looking to Table 4.2, I illustrate some differences in how CIRI and PTS would code similar scenarios. Within the states I examine in this dissertation (i.e. presidential democracies), Indonesia 2011 is the most populous country-year, while Cyprus is the least populous country for that year. If, hypothetically, 50 citizens were killed in both country-years, and there were no other human rights violations, both Indonesia 2011 and Cyprus 2011 would receive a CIRI score of '6' out of a possible high score of ' 8 '. This is because-referring back to Table 3.1-both states would received a score of ' 2 ' (indicating zero violations) for torture, disappearance, and political imprisonment, but a score 
of ' 0 ' (indicating 50 or more violations) for summary executions. Added together, the four constituent indicators produce a CIRI score of ' 6 '. Now, still looking at Indonesia 2011 and Cyprus 2011, if 50 citizens are imprisoned, then tortured, then they disappear, and then are killed (after first presumably re-appearing), both country-years would receive identical scores (as this scenario would equate to a score of ' 0 ' for all four constituent indictors, which produces a additive score of ' 0 ' out of a possible high score of ' 8 '). Note that CIRI counts instances of repression; both high-population and low-population states receive the same score for the same instances of repression. CIRI coders "do not rank countries relative to one another" (Cingranelli and Richards 2010: 406).

Table 3.2: Comparing CIRI versus PTS using scenarios.

\begin{tabular}{|c|c|c|}
\hline \multicolumn{3}{|c|}{ CIRI score when... } \\
\hline State (Population) & $\begin{array}{c}50 \text { citizens } \\
\text { are killed }\end{array}$ & $\begin{array}{l}50 \text { citizens are imprisoned, tortured, } \\
\text { disappear, and are then killed }\end{array}$ \\
\hline Indonesia $2011(243,810,051)$ & 6 out of 8 & 0 out of 8 \\
\hline Cyprus $2011(1,116,490)$ & 6 out of 8 & 0 out of 8 \\
\hline \multicolumn{3}{|c|}{ PTS score when... } \\
\hline State (Population) & $\begin{array}{c}50 \text { citizens } \\
\text { are killed } \\
\end{array}$ & $\begin{array}{l}50 \text { citizens are imprisoned, tortured, } \\
\text { disappear, and are then killed }\end{array}$ \\
\hline Indonesia $2011(243,810,051)$ & 2 out of 5 & 2 out of 5 \\
\hline Cyprus $2011(1,116,490)$ & 3 out of 5 & 3 out of 5 \\
\hline
\end{tabular}

Note that higher CIRI scores indicate better human rights practices, while lower PTS scores indicate better human rights practices.

While CIRI would score both Indonesia 2011 and Cyprus 2011 the same under the two scenarios I have described in Table 4.2, PTS would score the two country-years differently. This is because the coders of PTS assert that "the relative scope of violations within a state matters" (Wood and Gibney 2010: 399). Returning to the scenarios in Table 
4.2, 50 people being killed out of Cyprus 2011's roughly 1.1 millions citizens equates to a much larger proportion of the population being affected by repression compared to 50 people being killed out of Indonesia 2011's roughly 243.8 million citizens. As such, Indonesia's PTS score would likely be '2' (compared to a possible high score of '1'), while Cyprus would likely receive a ' 3 ' (compared to a possible high score of ' 1 '). In fact, for the proportion of the population affected by repression to be identical for both countryyears, for every 50 people killed in Cyprus, over 10 thousand people would have to have been killed in Indonesia. Unlike CIRI, changing the scenario from 50 citizens being killed to 50 citizens being imprisoned, then tortured, then made to disappear, then killed (after first presumably re-appearing) does not change the PTS score for either Indonesia 2011 or Cyprus 2011. This is because PTS takes into account the range of the population affected by repression as opposed to counting specific instances of repression. As such, Wood and Gibney (2010: 294) argue that "PTS better captures the relative severity of abuse across countries."

Despite their differences, both CIRI and PTS code 'physical integrity' rights (i.e. freedom from torture, summary execution, disappearance, and political imprisonment). As such, some scholars use PTS scores as a check for robustness when estimating CIRI scores, an example of which would be Cingranelli and Filippov (2010). More recent studies, however—such as Richards, Webb, and Clay (2015) — entirely rely on CIRI. One reason for this is that CIRI and PTS code state-sanctioned human rights violations very differently (as illustrated in Tables 3.1 and 3.2). A second reason is that CIRI and PTS code violations committed by non-state actors very differently; this difference being that CIRI does not factor in violations committed by non-state actors, while PTS does factor in 
such violations. ${ }^{1}$ For this study, I am not interested in how non-state actors affect human rights respect in presidential democracies. Instead, my emphasis is on how a runoff rule affects the leadership within presidential democracies, which in turn should affect government respect for human rights in those states. Given this emphasis, I utilize the CIRI scale as my dependent variable, as using the CIRI scale is the most appropriate way to estimate government respect for human rights in presidential democracies. Note that the CIRI scale is only available up until 2011 which provides a temporal limitation of this study. ${ }^{2}$

\subsection{Independent variables}

At this point, I direct your attention back to the Figure 2.9, which illustrates my overall theoretical argument. Per P4, I argue that in comparison to when there is a small distance between the president and the median voter, when there is a large distance between the president and the median voter, that state is less likely to be associated with a high government respect for human rights (which, as mentioned, I measure using the CIRI scale). In order to test this premise, I have constructed the following variable: president's distance from the median voter. To construct this variable, I needed to estimate the ideological position of the median voter for each democratic presidential election. I then needed to measure the distance between the position of the median voter and the position of the candidate that won the election.

\footnotetext{
${ }^{1}$ See the following: Gibney and Dalton (1996); Cornett and Gibney (2005); Wood and Gibney (2010).

${ }^{2}$ For the remainder for this dissertation, all references to 'human rights' specifically refer to the four 'physical integrity' rights measured by the CIRI scale (i.e. freedom from torture, summary execution, disappearance, and political imprisonment). Although, for the sake of simplicity, I effectively use the terms 'human rights' and 'physical integrity' rights interchangeably, this does not imply that physical integrity rights can be viewed as a proxy for all human rights, nor does it imply that the conclusions of this study extend to all human rights.
} 
In order to determine the position of the median voter, I first used manifesto data (Lehmann et. al 2017, Volkens et al. 2017) to identify the position of each political party that contested each direct, democratic, multi-candidate presidential election during each of the years for which I had CIRI scores. ${ }^{3}$ Using a method devised by Kim and Fording (1998, 2003), I then estimated the position of the median voter by accounting for the ideologies of the parties that contested the election as well as the vote share that each party received. ${ }^{4}$ I then took the absolute value of the ideology score of the median voter subtracted from the ideology score of the candidate that ultimately won the election in order estimate each president's distance from the median voter. ${ }^{5}$ Finally, I normalized this variable, such that values closer to 0 indicate that the president's distance from the median voter is low (compared to the other candidates that contested the election), while values closer to 1 suggest that the president's distance from the median voter is $h$ igh ${ }^{6}{ }^{6}$ In Figure 3.1, I present each of the elections for which I have computed the president's distance from the median voter. ${ }^{7}$ This figure allows the reader to easily see and compare how centrist various democratic presidents were. ${ }^{8}$

\footnotetext{
${ }^{3}$ Like Neto (2006) and Yazici (2019), I assume that the ideology of the political party that president candidates belong to is an accurate reflection of the ideology of the presidential candidates themselves.

${ }^{4}$ Essentially I use the following formula: $m=l+(50-c) / f * w$, where $m$ is the median voter's estimated ideology score, $l$ is the lower end of the 'interval' containing the median, $c$ is the cumulative vote share up to but not including the 'interval' containing the median, $f$ is the vote share of the 'interval' containing the median, and $w$ is the width of the 'interval' containing the median. Each party's 'interval' is calculated as the midpoint between that party and the one immediately left and right of it per simple Euclidean preference relations (i.e., voters choose the candidates/parties that are closest to them).

${ }^{5}$ For obvious reasons, elections where the president was any independent were omitted for this particular variable, as independents do not have an ideology score (which are needed to estimate the position of both the median voter and the president's distance from the median voter).

${ }^{6}$ To normalize, I used the following formula: $z_{i}=\left(x_{i}-\min (x)\right) /(\max (x)-\min (x))$, where $x=\left(x_{1}, \ldots, x_{n}\right)$ and $z_{i}$ is now my $i^{\text {th }}$ normalized value.

${ }^{7}$ Note that the manifesto data that I use to compute these values (Lehmann et. al 2017, Volkens et al. 2017) does not currently cover any political parties in Africa, and that coverage is limited for the Americas. However, using the method I have outlined above, expanded coverage for the president's distance from the median voter can be computed once new data becomes available.

${ }^{8}$ Note that I apply the president's distance from the median voter value to each year that the president was
} 
Figure 3.1: The president's distance from the median voter in 14 democracies.

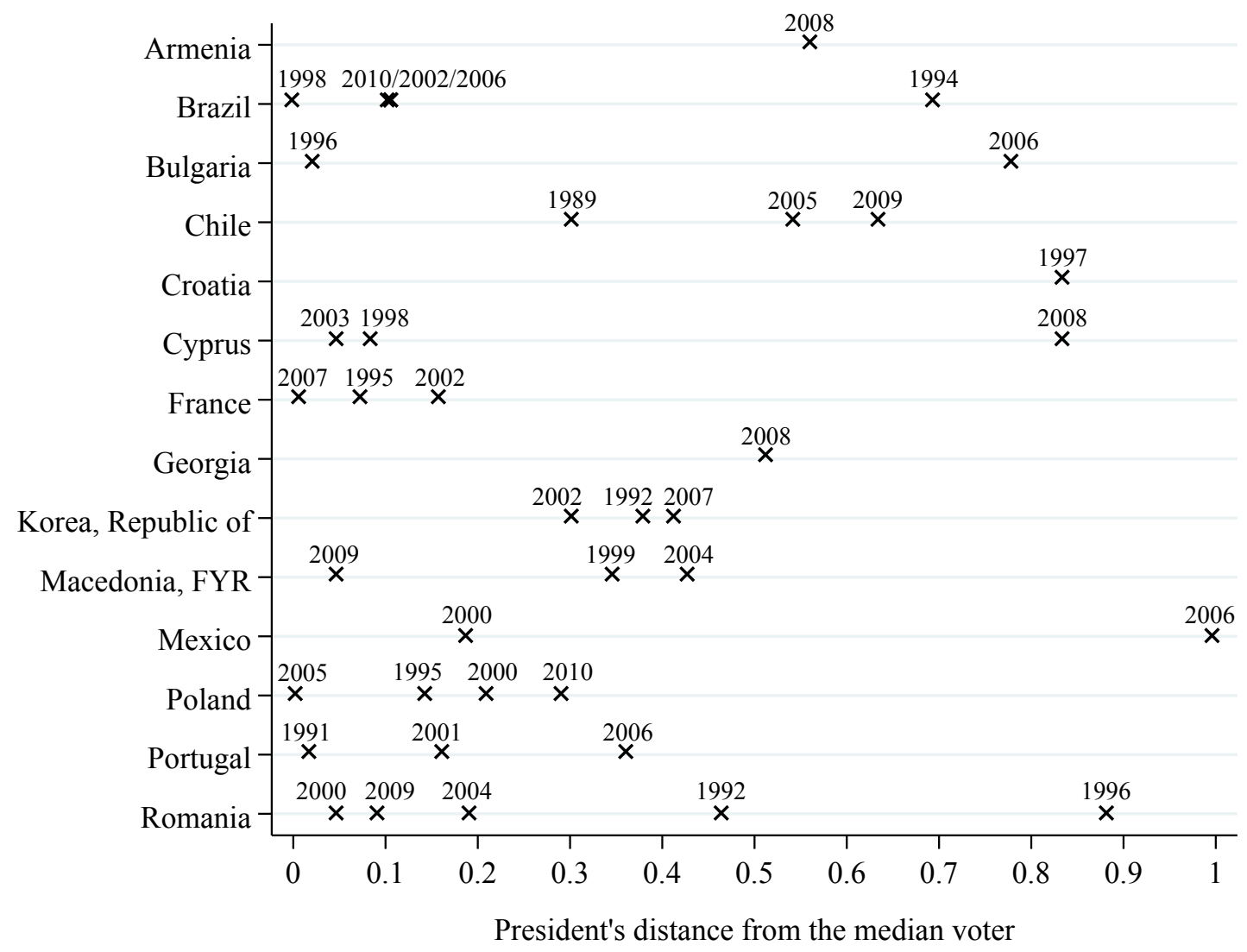

Per P5, I argue that in comparison to when the cabinet is comprised of a small percentage of members in the same party as the president, when the cabinet is comprised of a large percentage of members in the same party as the president, that state is less likely to be associated with high government respect for human rights. In order to test this premise, I have constructed the following variable: percent of the cabinet in the same party as the president. This variable was constructed by using the Central Intelligence Agency's (CIA) Chiefs of State and Cabinet Members of Foreign Governments directory. ${ }^{9}$ The year 2001 is the first for which this directory has data, and for each year since 2001, in power (up until the next election). Like Yazici (2019), I assume that the ideology of the president is constant between elections.

${ }^{9}$ Available at: https://www.cia.gov/library/publications/world-leaders-1/ 
this directory provides a monthly description of the cabinets for each country with which the United States maintains a diplomatic relationship. Using this data, I looked up who is in each cabinet for each country where data was available during the years 2001-2011 (as those are the only years that both the CIA directory and CIRI data are available). ${ }^{10}$ The reference month for each year was the same month as that of the last presidential election. Once all the cabinets were compiled for countries with available data, my percent of the cabinet in the same party as the president variable was constructed by dividing the number of cabinet ministers in the same party as the president by the total number of cabinet-level positions in that country for that year. ${ }^{11}$

Per P6, I argue that in comparison to when the president is elected with a majority, when the president is elected without a majority, that state is less likely to be associated with high government respect for human rights. In order to test this premise, I have constructed the following variable: president is elected without a majority. To construct this variable, for each country-year, I looked up the most recent election which had brought the current president into power. If, during that election, the president received less than 50\% of the vote, this country-year is coded as ' 1 '. For all country-years where the president had been elected with more than $50 \%$ of the vote, this variable is coded as ' 0 '.

Finally, per my hypothesis, I argue that in comparison to when the president is elected without a runoff rule, when the president is elected using a runoff rule, that state is more likely to be associated with high government respect for human rights. In order to test this hypothesis, I have constructed the following variable: president is elected using a

\footnotetext{
${ }^{10}$ My primary sources for identifying the political party affiliation for cabinet member were: Banks, Muller, and Overstreet (2003, 2007, 2008, 2009); Banks, Muller, Overstreet, and Isacoff (2010, 2011, 2012); Muller, Isacoff, and Lansford (2013); and finally Bértoa (2016).

${ }^{11}$ Note that in the Appendix, I provide an alternate version of this variable where I only examine whether the justice minister is in the same party as the president.
} 
runoff rule. To construct this variable, for each country-year, I again looked up the most recent election which had brought the current president into power. If, during that election, a runoff rule was in place, this country-year is coded as ' 1 '. For all country-years where there had not been a runoff provision in the previous election, this variable is coded as ' 0 '.

\subsection{Control variables}

The control variables I use to test my hypothesis are all standard within the human rights literature. These include a state's gross domestic product (GDP) per capita, population, level of civil conflict, a measure of how many checks there are on the executive, and finally a lagged of dependent variable.

To begin, following in the footsteps of Bueno de Mesquita et al. (2005: 450) who first identified that "elections in conjunction with executive constraints... enhance the protection of personal integrity rights," many human rights scholars have opted to include Polity IV's executive constraints (i.e. XCONST) variable as a control. ${ }^{12}$ Marshall, Gurr, and Jaggers (2014: 62) code this variable on a 7-point scale ranging from "unlimited executive authority" to "executive parity or subordination" based on "[t]he degree of checks and balances between the various parts of the government." The problem, however, is that since this XCONST measure was designed to estimate executive authority across all states, it does not fully capture the variation within specifically presidential democracies. For instance, while XCONST may distinguish between the powers of a president and that of an absolute monarch, it does not offer much distinction between different types of democratic presidents.

\footnotetext{
${ }^{12}$ A sample of some such scholars include the following: Davenport (2007); Richards and Gelleny (2007);
} Hafner-Burton, Hyde, and Jablonski 2014). 
Duverger (1970), for instance, identifies that while his native France is a system led by a president, there are also several parliamentary features, such as a prime minister. Duverger (1980) ultimately labels such systems as 'semi-presidential,' which he defines as a state where there is a popularly-elected president vested with considerable constitutional power, but there is also a prime minister and cabinet that are subject to the confidence of an assembly majority. Shugart and Carey (1992) propose that 'semipresidentialism' can be further divided into two subtypes: 'president-parliamentarism' and 'premier-presidentialism.' In a pure presidential system, the cabinet serves as long as it retains the confidence of the president. In a pure parliamentary system, the cabinet, led by the prime minister, serves as long as it retains the confidence of the assembly. In Shugart and Carey's (1992) 'president-parliamentary' subtype, the prime minister and cabinet are dually accountable to both the president and the assembly majority. The classic example of this would be the Weimar Republic between 1919 and 1933. More modern examples would be France and Portugal. In Shugart and Carey's (1992) 'premier-presidential' subtype, the prime minister and cabinet are exclusively accountable to the assembly majority. Examples of this would be Poland and Romania.

Among the 'president-parliamentary' and 'premier-presidential' subtypes, the president is much more powerful in the former, as he or she can both select and dismiss the prime minister and cabinet at will. As a result, Shugart (2005: 333) argues that "this form of semi-presidentialism is much closer to pure presidentialism." In a typical premierpresidential system, however, the prime minister and cabinet can only be dismissed by the assembly. "The fact that a president in such a system cannot guarantee that his or her preferred cabinet can remain in place... is a feature that restricts the president's real 
choice of prime-ministerial candidate" (Shugart 2005: 333). Presidential power is therefore relatively weaker in premier-presidential systems, in comparison to both presidentparliamentary systems and pure presidential systems.

Recently, Doyle and Elgie (2016) have created a measure of presidential power that seeks to account for the differing levels of executive authority that exists across different presidential systems. They note that while "some studies have estimated the effect of variation in the level of constraints on the executive in the system of checks and balances by operationalizing Polity's XCONST variable" (Doyle and Elgie 2016: 732), this measure does not account for all the variation between various pure-presidential, presidentparliamentary, and premier-presidential systems around the world. ${ }^{13}$ In contrast, Doyle and Elgie's (2016) new measure of presidential power pools together "twenty-eight existing measures... using a method that accounts for the idiosyncrasies of country scores in existing measures." This new measure better accounts for the wide range of institutional variables that could affect government respect for human rights.

Next, for years, human rights scholars have argued that "regimes are more coercive when they are involved in civil conflict" (Poe and Tate 1994: 859). As such, I include a measure of civil conflict that is derived from version 4-2015 of the UCDP/PRIO Armed Conflict Dataset (Gleditsch et al. 2002; Pettersson and Wallensteen 2015). I chose this conflict variable (among others) as it seems to be more commonly used in the human rights literature. ${ }^{14}$ This variable is coded as ' 0 ' for each country-year with less than 25

\footnotetext{
${ }^{13}$ Richards and Gelleny (2007), for instance, examine government respect for human rights in democratic pure-presidential and semi-presidential states (just as this dissertation does). They explain that they have included the XCONST measure in their regressions in order " $[\mathrm{t}] \mathrm{o}$ account for differing levels of executive authority across different systems with presidential elections."

${ }^{14}$ See, for instance, the following literature: Richards and Gelleny (2007); Richards, Webb, and Clay (2015); Clay and DiGiuseppe (2017).
} 
battle-related deaths, ' 1 ' for each country-year where there were between 25 and 999 battle-related deaths, and finally ' 2 ' for each country-year where there were more than 999 battle-related deaths.

I have also included two demographic variables: one based on a state's gross domestic product (GDP) and another based on its population. Banks (1989) argues that a relationship exists between low income levels and low levels of freedom, as does Henderson (1991) and Mitchell and McCormick (1988). Henderson (1993) argues that there is a relationship between high population and low government respect for human rights. Other studies have similarly linked both GDP per capita and population size with human rights violations. ${ }^{15}$ My GDP per capita and population size variables are both from the World Bank (2015), and both are natural logged so as to correct their distributional nature (Tufte 1974).

Finally, a state's previous year's level of government repression likely influences whether the following year will also experience repression. Since "[p]atterns of abuse tend to persist over time," I follow Bueno de Mesquita et al. (2003: 352) in "including a lagged dependent variable allows." I refer to this variable as: previous year's score on the CIRI scale. In Table 3.3, the summary statistics for this variable-as well as all of my other variables — can be found. In the next chapter, I will use these variables to first test my six premises, then to test hypothesis.

\footnotetext{
${ }^{15}$ A sample of such studies include the following: Poe and Tate (1994); Poe, Tate, and Keith (1999); Richards, Webb, and Clay (2015).
} 
Table 3.3: Summary statistics.

\begin{tabular}{lccccc}
\hline & Obs & Mean & Std Dev & Min & Max \\
\hline President's distance from the median voter & 164 & 0.304 & 0.277 & 0 & 1 \\
Percent of the cabinet in the same party as the president & 241 & 0.448 & 0.312 & 0 & 1 \\
President is elected without a majority & 828 & 0.175 & 0.380 & 0 & 1 \\
President is elected using a runoff rule & 828 & 0.758 & 0.428 & 0 & 1 \\
Presidential power & 828 & 0.351 & 0.156 & 0.030 & 0.657 \\
Civil conflict & 828 & 0.128 & 0.412 & 0 & 2 \\
(Logged) population size & 828 & 16.202 & 1.240 & 766,584 & $243,810,050$ \\
(Logged) GDP per capita & 828 & 8.890 & 1.013 & $\$ 580$ & $\$ 44,000$ \\
Previous year's score on the CIRI scale & 828 & 5.124 & 2.019 & 0 & 8 \\
\hline
\end{tabular}




\section{Chapter 4}

\section{Results}


In this chapter I begin by using bivariate analysis to test my first three premises in order to demonstrate that the presence of a runoff rule reduces the following: the distance between the president and the median voter (i.e. P1), the percentage of cabinet members in the same party as the president (i.e. P2), and finally the likelihood that the president is elected without a majority (i.e. P3). Next, I use regression analysis to test P4, P5, and P6, in order to demonstrate that each of the three outcomes above are negatively associated with high government respect for human rights (see Figure 2.9). I then test my hypothesis, and follow-up by discussing the substantive effects of my regression models.

\subsection{Bivariate analysis}

Recall that $\mathbf{P 1}$ suggests that in comparison to when the president is elected without a runoff rule, when the president is elected using a runoff rule, there is likely a reduced distance between the president and the median voter. Because my president is elected using a runoff rule variable is binary, while my president's distance from the median voter variable is continuous, a two-sample $t$-test is the most appropriate way to test their relationship. An assumption of this test is that variances are approximately equal; therefore, before conducting this test, it is prudent to first test for equal variances.

In Table 4.1, I present values for Levene's (1960) test of equal variances, as well as two variants of this test proposed by Brown and Forsythe (1974), which use more robust estimators of central tendency (e.g., the median and $10 \%$ trimmed mean). As you can see in Table 4.1, none of the $p$-values for any of the three test statistics are statistically significant. This indicates that the variances are roughly equal, and I can proceed with a two-sample $t$-test with equal variances. Consistent with P1, the results in Table 4.2 report 
that the $t$-statistic is significant at the $99 \%$ level, indicating that there is a statistically significant difference between the mean president's distance from the median voter score for presidents that were elected using a runoff rule versus the mean president's distance from the median voter score of presidents that were not elected using a runoff rule.

Table 4.1: Testing the equality of variances between the president being elected using a runoff rule and the president's distance from the median voter.

\begin{tabular}{c|c|cc}
\hline \multirow{2}{*}{ President is elected using a runoff rule } & \multirow{2}{*}{ Observations } & \multicolumn{2}{|c}{ President's distance from the median voter } \\
& & Mean & Standard deviation \\
\hline 0 & 25 & 0.449 & 0.292 \\
1 & 139 & 0.278 & 0.267 \\
\hline Combined & 164 & 0.304 & 0.277 \\
\hline
\end{tabular}

Levene's test statistic using the mean $=0.021$

Levene's test statistic using the median $=0.127$

Levene's test statistic using the $10 \%$ trimmed mean $=0.000$ $* p<0.10, * * p<0.05, * * * p<0.01$.

Table 4.2: Testing the relationship between the president being elected using a runoff rule and the president's distance from the median voter using a two-sample $t$-test (with equal variances).

\begin{tabular}{|c|c|c|c|}
\hline \multirow{2}{*}{ President is elected using a runoff rule } & \multirow{2}{*}{ Observations } & \multicolumn{2}{|c|}{ President's distance from the median voter } \\
\hline & & Mean & 95\% Confidence Interval \\
\hline 0 & 25 & 0.449 & {$[0.329,0.570]$} \\
\hline 1 & 139 & 0.278 & {$[0.233,0.323]$} \\
\hline Combined & 164 & 0.304 & {$[0.261,0.347]$} \\
\hline Difference & & 0.172 & {$[0.055,0.288]$} \\
\hline
\end{tabular}

Recall that P2 suggests that in comparison to when the president is elected without a runoff rule, when the president is elected using a runoff rule, there is likely a reduced percentage of cabinet members in the same party as the president. Again, because my 
president is elected using a runoff rule variable is binary, while my percent of the cabinet in the same party as the president variable is continuous, a two-sample $t$-test is the most appropriate way to test their relationship. As mentioned above, an assumption of this test is that variances are approximately equal; therefore, before conducting this test, it is again prudent to first test for equal variances.

In Table 4.3, I present values for Levene's (1960) test of equal variances, as well as the two variants of this test proposed by Brown and Forsythe (1974). As you can see in Table 4.3, the $p$-values are all highly significant, indicating that the variances are not equal. In order to correct for this, I use Satterthwaite's (1946) approximation of the effective degrees of freedom when estimating a two-sample $t$-test with unequal variances. Consistent with P2, the results in Table 4.4 report that the $t$-statistic is significant at the $99 \%$ level, indicating that there is a statistically significant difference between the mean percent of the cabinet in the same party as the president score for presidents that were elected using a runoff rule versus the mean percent of the cabinet in the same party as the president score of presidents that were not elected using a runoff rule.

Table 4.3: Testing the equality of variances between the president being elected using a runoff rule and the percent of the cabinet in the same party as the president.

\begin{tabular}{c|c|cc}
\hline President is elected using a runoff rule & Observations & \multicolumn{2}{|c}{$\begin{array}{c}\text { Percent of the cabinet in the same party } \\
\text { as the president } \\
\text { Standard deviation }\end{array}$} \\
\hline 0 & 54 & 0.613 & 0.225 \\
1 & 187 & 0.401 & 0.318 \\
\hline Combined & 241 & 0.448 & 0.312 \\
\hline
\end{tabular}

Levene's test statistic using the mean $=13.770 * * *$

Levene's test statistic using the median $=13.057 * * *$

Levene's test statistic using the $10 \%$ trimmed mean $=15.991 * * *$

* $p<0.10, * * p<0.05, * * * p<0.01$. 
Table 4.4: Testing the relationship between the president being elected using a runoff rule and the percent of the cabinet in the same party as the president using a two-sample $t$-test (with unequal variances).

\begin{tabular}{|c|c|c|c|}
\hline \multirow{2}{*}{ President is elected using a runoff rule } & \multirow{2}{*}{ Observations } & \multicolumn{2}{|c|}{$\begin{array}{l}\text { Percent of the cabinet in the same party } \\
\text { as the president }\end{array}$} \\
\hline & & Mean & 95\% Confidence Interval \\
\hline 0 & 54 & 0.613 & {$[0.551,0.674]$} \\
\hline 1 & 187 & 0.401 & {$[0.355,0.447]$} \\
\hline Combined & 241 & 0.448 & {$[0.409,0.488]$} \\
\hline \multicolumn{2}{|l|}{ Difference } & 0.212 & {$[0.136,0.288]$} \\
\hline
\end{tabular}

$t$-statistic $=5.515^{* * *}$

$* p<0.10, * * p<0.05, * * * p<0.01$.

Recall that $\mathbf{P 3}$ suggests that in comparison to when the president is elected without a runoff rule, when the president is elected using a runoff rule, there is a reduced likelihood that the president is elected without a majority. Because both my president is elected using a runoff rule and president is elected without a majority variables are binary, Fisher's (1934) exact test is the most appropriate way to test their relationship. Note that Fisher's exact test does not have a 'test statistic' but rather computes the $p$-value directly (hence why it is called an 'exact' test). As you can see in Table 4.5, the p-value is highly significant, indicating that there is a nonrandom association between these two variables. Looking more closely at this table, you can see that when the president had been elected without a runoff rule, roughly $53 \%$ of the time that president had also been elected without a majority. In contrast, when the president had been elected using a runoff rule, only about $6 \%$ of the time had that president been elected without a majority. ${ }^{1}$

\footnotetext{
${ }^{1}$ While this result may look strange, recall from Chapter 2 that while most states that use a runoff rule require that at least one candidate obtain at least $50 \%$ of the vote, in some states this is not the case. For instance, in Costa Rica, a candidate with $40 \%$ of the vote can avoid a runoff. In Argentina, a candidate with $45 \%$ of the vote can avoid a runoff, or they can also avoid a runoff by netting $40 \%$ of the vote and have at least a $10 \%$ lead over the second-place candidate. Finally, in Nicaragua, a candidate with $40 \%$ of the vote can avoid a runoff, or they can also avoid a runoff by netting $35 \%$ of the vote and have at least a $5 \%$ lead over the second-place candidate.
} 
Table 4.5: Testing the relationship between the president being elected using a runoff rule and the president being elected without a majority using Fisher's exact test.

\begin{tabular}{c|cc|c}
\hline President is elected using a runoff rule & \multicolumn{2}{|c|}{ President is elected without a majority } & \\
& 0 & 1 & Total \\
\hline 0 & $94[47 \%]$ & $106[53 \%]$ & 200 \\
1 & $589[94 \%]$ & $39[6 \%]$ & 628 \\
\hline Total & $683[82 \%]$ & $145[18 \%]$ & 828 \\
\hline \multicolumn{4}{r}{$p$-value $<0.001$} \\
\hline
\end{tabular}

\subsection{Regression analysis}

In Table 4.6, I present the results of four ordered logit regressions that estimate CIRI scores in presidential democracies from 1990 to 2011 . The first three of these regressions correspond to $\mathbf{P 4}, \mathbf{P 5}$, and $\mathbf{P 6}$, while the fourth regression corresponds to my hypothesis (see Figure 2.9 for an overview). Recall that my dependent variable is government respect for human rights, as measured using the CIRI scale. Given that the scale is ordinal, an ordinary least squares regression would lead to biased inferences as distances between the categories of the dependent variable are not equal (McKelvey and Zavoina 1975). Instead, the ordered nature of the CIRI scale lends itself to the use of ordered logit estimation (McCullagh 1980).

Beginning with Model 1, recall that with P4, I argue that in comparison to when there is a small distance between the president and the median voter, when there is a large distance between the president and the median voter, that state is less likely to be associated with a high government respect for human rights. Consistent with this premise, Model 1 reports that my primary independent variable_president's distance from the median voter - is negatively associated with high scores on the CIRI scale (which, as men- 


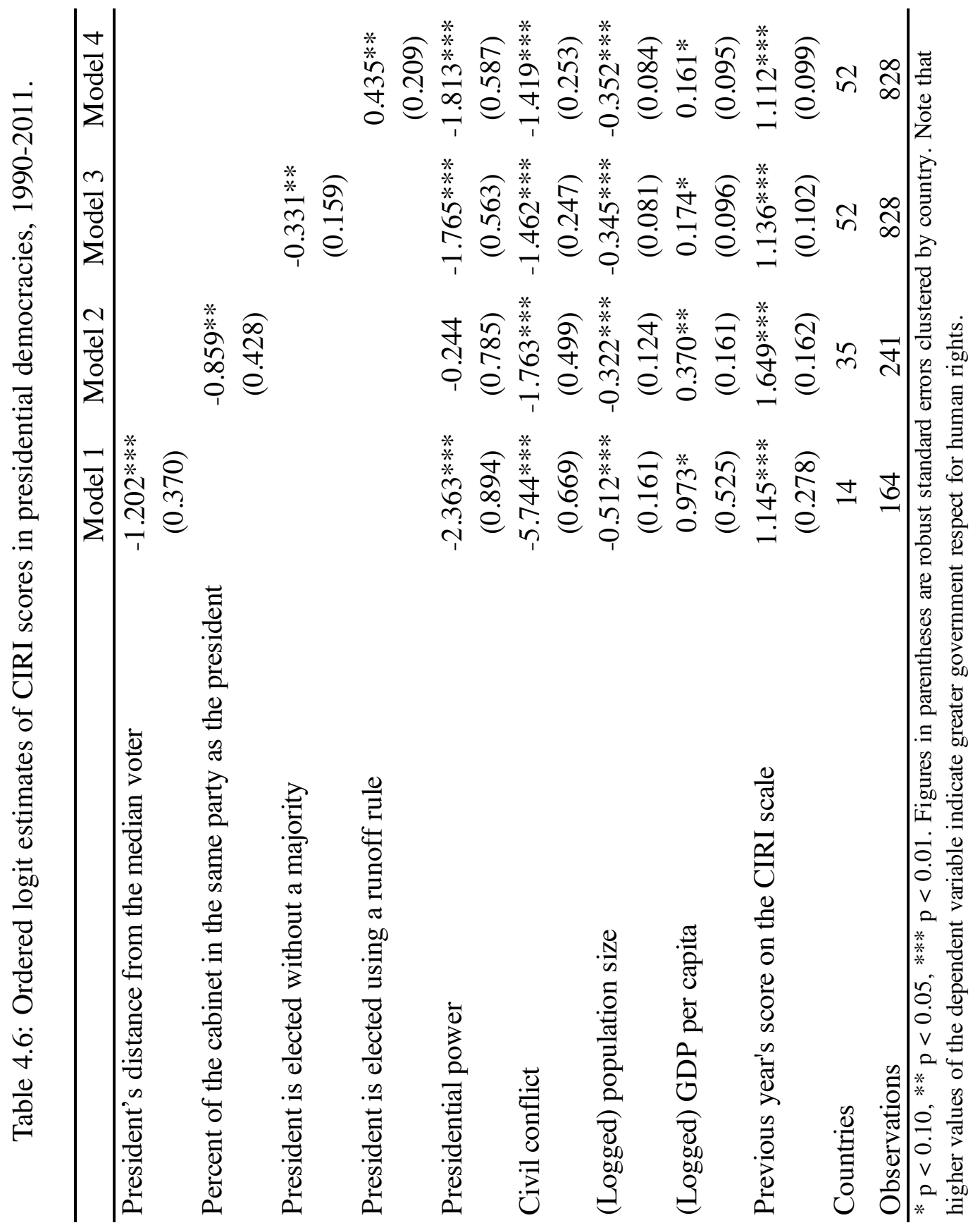


tioned, indicates greater government respect for human rights), and that this relationship is statistically significant at the $99 \%$ level. For Model 2, recall that with P5, I argue that in comparison to when the cabinet is comprised of a small percentage of members in the same party as the president, when the cabinet is comprised of a large percentage of members in the same party as the president, that state is less likely to be associated with high government respect for human rights. Consistent with this premise, Model 2 reports that my primary independent variable-percent of the cabinet in the same party as the president - is negatively associated with high scores on the CIRI scale, and that this relationship is statistically significant at the 95\% level. ${ }^{2}$ For Model 3, recall that with P6, I argue that in comparison to when the president is elected with a majority, when the president is elected without a majority, that state is less likely to be associated with high government respect for human rights. Consistent with this premise, Model 3 reports that my primary independent variable—president is elected without a majority—is negatively associated with high scores on the CIRI scale, and that this relationship is statistically significant at the $95 \%$ level. Finally, for Model 4, recall that with my hypothesis, I argue that in comparison to when the president is elected without a runoff rule, when the president is elected using a runoff rule, that state is more likely to be associated with high government respect for human rights. Consistent with this hypothesis, Model 4 reports that my primary independent variable—president is elected using a runoff rule—is positively associated with high scores on the CIRI scale, and that this relationship is statistically significant at the $95 \%$ level.

\footnotetext{
${ }^{2}$ Note that in the Appendix, I provide an alternate version of this model where I only examine whether the justice minister is in the same party as the president.
} 
Consistent with previous human rights scholarship, across all four models all statistically significant control variables have signs pointing in the expected direction. For instance presidential power, civil conflict, and (logged) population size are all found to be negatively associated with high scores on the CIRI scale, while (logged) GDP per capita and previous year's score on the CIRI scale are both found to be positively associated with high scores on the CIRI scale.

\subsection{Substantive effects}

While statistically significant regression coefficients are promising, a more intuitive understanding of the substantive effects of these relationships can be better communicated through an analysis of predicted probabilities. In Table 4.7, I outline the parameters of three scenarios which I use to form the basis of my predicted probabilities analysis. The 'Best' and 'Worst' scenarios are based on the 5th and 95th percentiles of my control variables, while the 'Average' scenario is based on each variable's mean (or mode in the case of civil conflict, which is categorical). ${ }^{3}$ Essentially, the 'Best' scenario represents a rich, less populous state that has a constitutionally-weak president, a history of high government respect for human rights, and no civil conflict. The 'Worst' scenario represents a poor, highly populous state that has a constitutionally-powerful president, a history of low government respect for human rights, and is experiencing some low-level civil conflict. Finally, the 'Average' scenario represents a state whose statistics are between the 'Best' and 'Worst' scenarios.

\footnotetext{
${ }^{3}$ Note that these percentiles were based upon the 828-observation sample that Model 3 and 4 use, as these samples were the largest, and thus, more likely reflective of the population.
} 
Table 4.7: Summary statistics of scenarios used in predicted probabilities analysis.

\begin{tabular}{|c|c|c|c|}
\hline & 'Best' scenario & 'Average' scenario & 'Worst' scenario \\
\hline Presidential power $^{a}$ & 0.101 & 0.351 & 0.644 \\
\hline Civil conflict ${ }^{\mathrm{b}}$ & 0 & 0 & 1 \\
\hline Population size & $1,982,958$ & $10,878,621$ & $116,418,265$ \\
\hline GDP per capita & $\$ 33,500$ & $\$ 7,258$ & $\$ 1,250$ \\
\hline Previous year's score on the CIRI scale ${ }^{c}$ & 8 & 5 & 2 \\
\hline
\end{tabular}

${ }^{a}$ Scores range from 0 to 1 ; higher values indicate more powerful presidents.

${ }^{\mathrm{b}}$ Scores range from 0 to 2 ; higher values indicate more civil conflict.

${ }^{\mathrm{c}}$ Scores range from 0 to 8 ; higher values indicate greater government respect for human rights.

In Tables 4.8, 4.9, 4.10, and 4.11, I present the predicted probabilities (with 95\% confidence intervals) of CIRI scores based upon changes in the primary independent variables of Models 1-4. These probabilities were estimated using the Clarify software package (Tomz, Wittenberg, and King 2003). Along with each of these predicted probabilities, I also report the probability 'difference' (with 95\% confidence intervals) when each my primary independent variables' value goes from the ' 1 ' to the ' 0 '. Finally, I report the 'percentage change,' which is essentially the 'difference' in this variable going from the ' 1 ' to ' 0 ' divided by the probability of this variable being at ' 1 '.

In Table 4.8 you can see the predicted probabilities of CIRI scores based upon changes in the president's distance from the median voter. Starting with the 'Best' scenario, you can see that the probability of an ' 8 ' on the the CIRI scale (i.e. the highest possible score for government respect for human rights) is 0.344 when the president's distance from the median voter is ' 1 ' (i.e. at the maximum), but is 0.616 when president's distance from the median voter is ' 0 ' (i.e. at the minimum). Note that the difference in the probability going from 0.344 to 0.616 is 0.272 , which—as you can see—is statistically significant at least at the the $95 \%$ level, given that the corresponding $95 \%$ confidence interval (which is in brackets) does not overlap with zero. Substantively, increasing a 0.344 


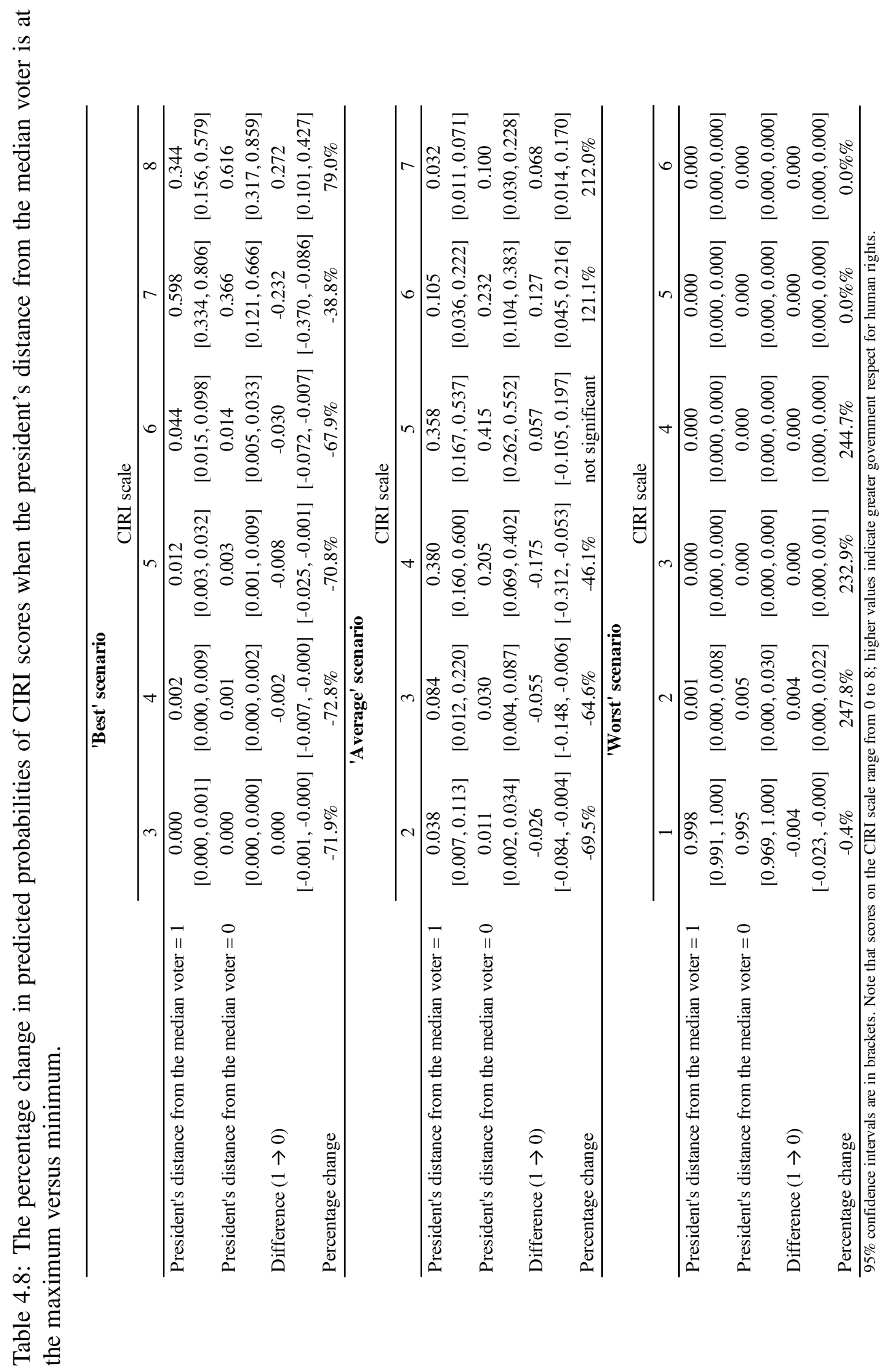


probability by 0.272 is a $79 \%$ increase. This means that in any given year, for a state that matches the 'Best' case parameters, that state is $79 \%$ more likely to be at the highest level of government respect for human rights when the president is as ideologically close to the median voter as possible.

Continuing with the 'Best' scenario, you can see that lower scores on the CIRI scale (i.e. scores of ' 3 ' through '7') all correspond with negative percent changes. For instance, a state is $70.8 \%$ less likely to be at the at score of ' 5 ' on the CIRI scale when the president is as ideologically close to the median voter as possible. In short, this suggests that states are more likely to experience greater government respect for human rights and less likely to experience lower government respect for human rights when the president is as ideologically close to the median voter as possible. Note that this trend continues throughout the 'Average' and 'Worst' scenarios.

Looking more closely at the 'Worst' scenario, however, you can see that this effect-while still statistically significant-is much less noticeable. For instance, you can see that the probability of an ' 1 ' on the the CIRI scale (which indicates a very low level of government respect for human rights) is 0.998 when the president's distance from the median voter is at the maximum, but is 0.995 when president's distance from the median voter is at the minimum. Note that the difference in the probability going from 0.998 to 0.995 is -0.004 (due to rounding), which, again, is statistically significant at least at the the 95\% level (given that the corresponding 95\% confidence interval does not overlap with zero). Substantively, however, decreasing a 0.998 probability by 0.004 is only a $0.4 \%$ decrease. So while a president that is as ideologically close to the median voter as possible is statistically less likely to associated with a score of ' 1 ' on the CIRI scale 
versus a president that is further from the median voter, the difference between the two probabilities is marginal. In other words, the positive affect that centrist presidents have on government respect for human rights is more pronounced in states that resemble the 'Best' and 'Average' scenarios, and less pronounced in states that more closely resemble the 'Worst' scenario. Regardless, the results reported in Table 4.8 clearly provide support for $\mathbf{P 4}$, which effectively argues that there is a negative association between my primary independent variable (i.e. president's distance from the median voter) being at ' 1 ' (i.e. the maximum) and high government respect for human rights.

I now direct your attention to Tables $4.9,4.10$, and 4.11, which report substantive effects of the association between my remaining primary independent variables (i.e. percent of the cabinet in the same party as the president for Table 4.9, president is elected without a majority for Table 4.10, and president is elected using a runoff rule for Table 4.11) being at ' 1 ' and high government respect for human rights. Consistent with P5, Table 4.9 suggests that states are more likely to experience greater government respect for human rights and less likely to experience lower government respect for human rights when $0 \%$ of the president's cabinet-members are in the president's party. Consistent with P6, Table 4.10 suggests that states are more likely to experience greater government respect for human rights and less likely to experience lower government respect for human rights when the president is elected with a majority. Finally, consistent with my hypothesis, Table 4.11 suggests that states are more likely to experience greater government respect for human rights and less likely to experience lower government respect for human rights when the president is elected using a runoff rule. 


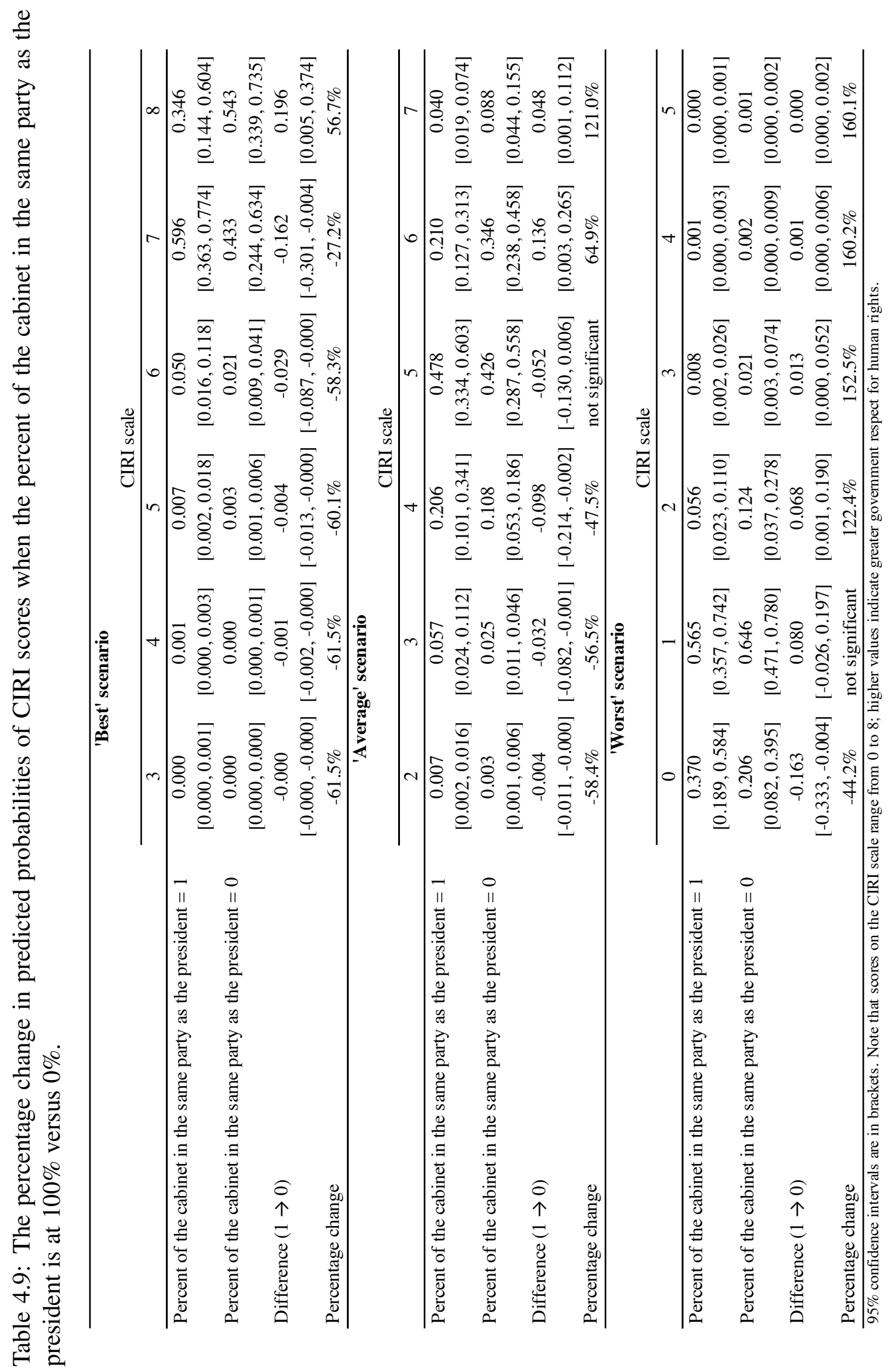




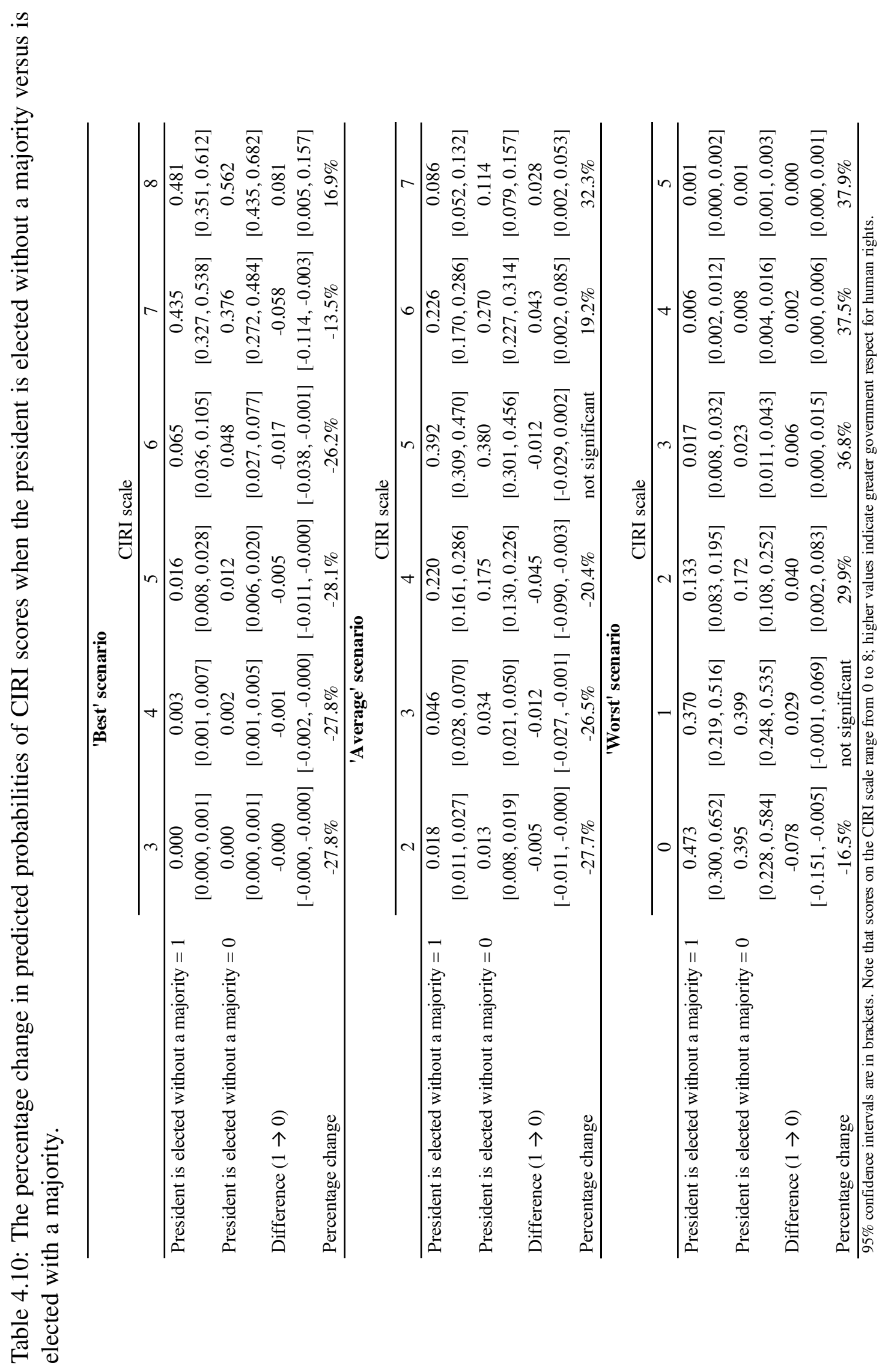




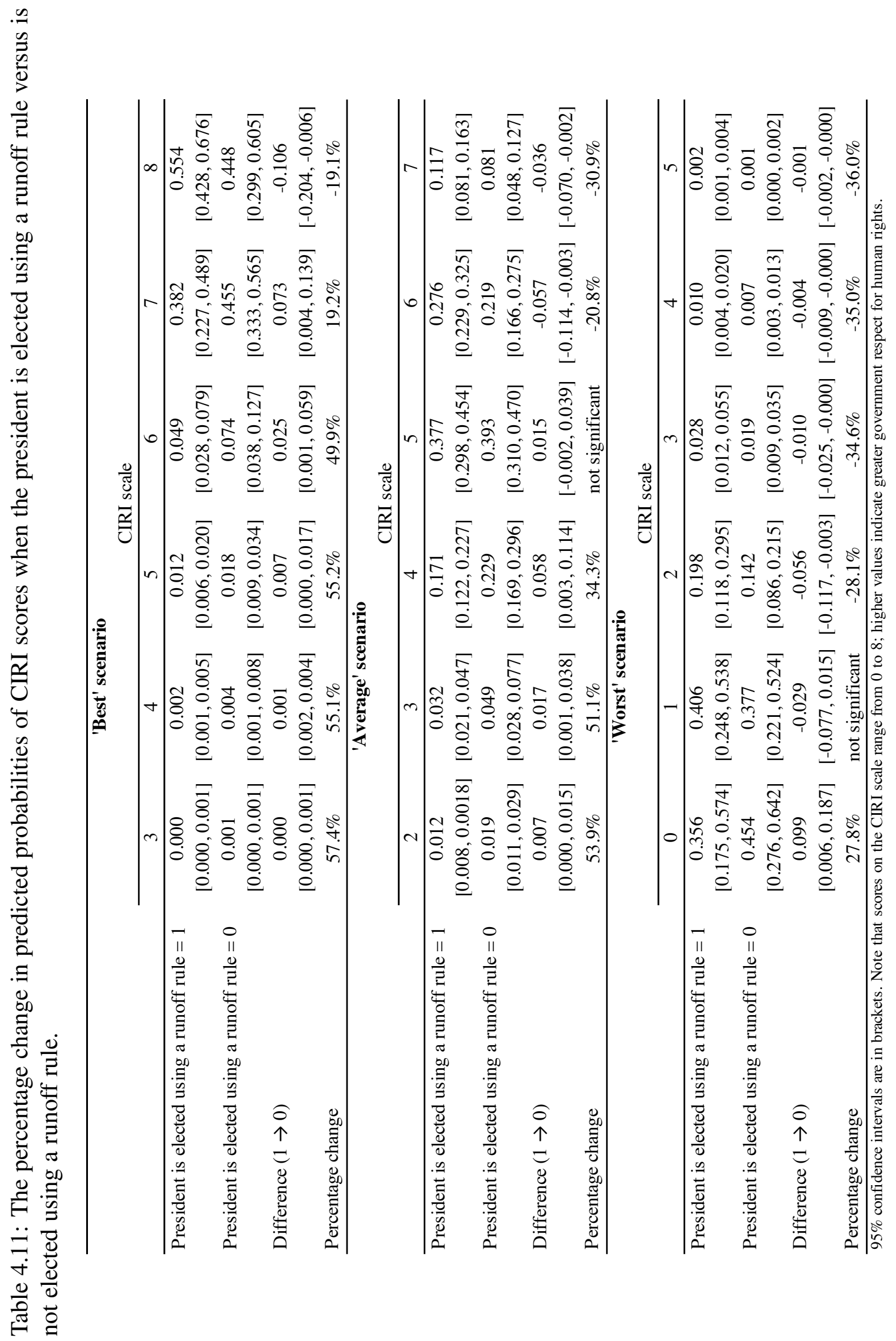


To review, I would like to direct your attention back to Figure 2.9, where I illustrate my overall theoretical argument. In this chapter, I have provided evidence in support of P1 (which argues that when the president is elected using a runoff rule, the likely result is a reduced distance between the president and the median voter), $\mathbf{P 2}$ (which argues that when the president is elected using a runoff rule, the likely result is a reduced percentage of cabinet members in the same party as the president), and $\mathbf{P 3}$ (which argues that when the president is elected using a runoff rule there is a reduced likelihood that the president is elected without a majority). Additionally, I have provided provided evidence in support of $\mathbf{P 4}$ (which argues that when there is a large distance between the president and the median voter, that state is less likely to be associated with a high score on the CIRI scale), P5 (which argues that when the cabinet is comprised of a large percentage of members in the same party as the president, that state is less likely to be associated with a high score on the CIRI scale), and $\mathbf{P 6}$ (which argues that when the president is elected without a majority, that state is less likely to be associated with a high score on the CIRI scale). Together, all of this suggest that a presidential runoff rule reduces determinants that are in turn negatively associated with high scores on the CIRI scale. As such—per my hypothesis—a runoff rule should be positively associated with a high score on the CIRI scale; with Model 4 in Table 4.6 and the substantive effects reported in Table 4.11, I have provided evidence of this. In the next chapter, I will conclude this dissertation with a short vignette to remind the reader that the focus of this dissertation has been on presidential democracies, and as such, the results I have presented in this chapter are unlikely to be observable outside of a democratic context. 


\section{Chapter 5}

\section{Conclusion}


Do elections increase or decrease the likelihood that governments respect human rights? Despite the answer to this question seeming intuitive, the literature on this topic has thus far been mixed. On one side of the debate, scholars argue that elections empower a population vis-à-vis its government, which thereby decreases the likelihood that a government will resort to repressing its own people. ${ }^{1}$ Mill (1991: 245), for instance, argues that "human beings are only secure from evil at the hands of others, in proportion as they have the power of. .. self-protecting." Bollen (1986) argues that this power of self-protecting comes as a result of political participation, which empowers the citizenry at the expense of elites, whose relative power is reduced. By allowing citizens to "express a choice among the alternatives" citizens are afforded the opportunity to reach decisions regarding what is best for the citizenry as a whole (Dahl 1989: 71). Elections, therefore, enable citizens to influence policy (Powell 2000). By aggregating input from the citizenry, elections "establish boundaries for governmental action" and thereby serve a "vital protective function" (Steiner 1988: 101-102). According to Dalton (1988: 205), elections first "provide an input mechanism that allows the opportunity for citizen involvement in the political process," and "[s]econd, they provide a motive for elected representatives to be accountable to their constituents." Through elections, citizens "confront the controllers and supporters of sets of social arrangements that determine patterns of access to resources, services, status and power" (Stiefel and Wolfe 1994: 6). When given a choice, citizens would not typically choose policies (or politicians) that they expect would infringe upon their rights; therefore, through elections, citizens are afforded the opportunity to promote government respect for human rights by casting their vote for who they believe will

\footnotetext{
${ }^{1}$ For an overview of this literature, see the following: Lipset (1963); Milnor (1969); Rose (1980); Booth and Seligson (1989); Lewis-Beck (1990); Sisk (1995).
} 
be mostly likely to guarantee such rights.

On the other side of this debate, however, some scholars argue that elections increase political polarization by challenging the established order and threatening the political system, which can lead to an increase in human rights violations. ${ }^{2}$ From this point of view, repression is viewed as a viable strategic option that governing elites could pursue in their attempt to maintain stability and control. ${ }^{3}$ This body of scholarship notes that "[m]any of the world's longest-standing consolidated democracies, including France, the United Kingdom and the United States, have experienced periods of... violence" (HafnerBurton, Hyde, and Jablonski 2014: 27). In one such study, Richards and Gelleny (2007: 517) find "presidential elections to be associated with lesser levels of respect."

So why is it that up until now elections have been found to increase the prospect of repression, but have also seemingly been found to protect against repression? In this dissertation, I have argued that it comes down to electoral rules. I argue that in comparison to when the president is elected without a runoff rule, when the president is elected using a runoff rule, that state is more likely to be associated with high government respect for human rights. I argue that this is the case because presidential elections that use a runoff rule reduce several determinants that are in turn negatively associated with high government respect for human rights. For instance, in this dissertation I have found that a large distance between the ideological position of the president and the median voter is negatively associated with high government respect for human rights. Additionally, I

\footnotetext{
${ }^{2}$ Example of this literature include: Herman and Brodhead (1984); Booth and Seligson (1989); Austin (1995); Seligson and Booth (1995); Collier (2009); Robinson and Torvik (2009); Collier and Vicente (2012).

${ }^{3}$ See for example: Walter (1969); Hibbs (1973); Pirages (1976); Piven and Cloward (1979); Gurr (1986); Ziegenhagen (1986); Lichbach (1987); Duvall and Stohl (1988); Franks (1989); Churchill and Vander Wall (1990); Petersen and Karklins (1993); Tarrow (1994); Davenport (1995); Francisco (1996).
} 
have found that cabinets comprised of a high percent of members in the same party as the president are negatively associated with high government respect for human rights. Furthermore, I have found that presidents elected without a majority are negatively associated with high government respect for human rights. ${ }^{4}$ Given that, I found that a presidential runoff rule reduces the distance between the ideological position of the president and the median voter, reduces the percent of the cabinet in the same party as the president, and reduces the likelihood that the president is elected without a majority, it is perhaps no surprise that I found that the presence of a runoff rule is positively associated with high government respect for human rights.

\subsection{An (re)emphasis on democracies}

As I come to a close, I want to reiterate what I stated in the Introduction: this dissertation only examines democratic presidential systems. My theory-and this study's results-may not (and probably will not) be observable outside of a democratic context. Indeed, while I argue that a runoff rule promotes government respect for human rights within democratic presidential systems, it is possible that in non-democracies, a runoff rule actually has the opposite effect.

For instance, the 2008 presidential election in Zimbabwe is an example of how a runoff rule may have actually facilitated a worsening of government respect for human rights. During the first round of this election, Zimbabweans made a seemingly simple and straightforward economic decision: tired of decades of mismanagement by the authoritarian Robert Mugabe and his corrupt Zimbabwe African National Union-Patriotic Front

\footnotetext{
${ }^{4}$ Note that for all three of these tests, I coded my own data, which itself is a contribution to the field.
} 
(ZANU-PF), a record number of citizens cast their vote for the Movement for Democratic Change's (MDC) Morgan Tsvangirai. Since the start of Mugabe-rule shortly after independence in 1980, Zimbabwe had embarrassingly went from the economically-prosperous 'breadbasket' of southern Africa to a net importer of food suffering from hyperinflation. However, after the first round of the 2008 election, the party with lower initial public support (i.e. Mugabe's ZANU-PF) ended up leveraging a multiple-decades-long incumbency advantage by devoting resources to creating political unrest with the intent of forcing a runoff round victory (Chaturvedi 2005). With political violence growing "increasingly severe as the second round approached," Mugabe ultimately "succeeded both in forcing the MDC to withdraw from the second round and in securing an incumbent-biased powersharing deal" (Collier and Vicente 2012: 137-138).

Had the 2008 presidential election in Zimbabwe not utilised a runoff rule, it is possible that Tsvangirai would have won, given that he had a plurality after the first round. As a result of a runoff rule, however, Mugabe was given a second chance to win. He was able to use the results from the first round as an indicator of how much he would need to ratchet up repression in order to force a win in the second round. This is illustrated by accounts that "at least 153 MDC supporters were killed between March and June 2008," and "[w]omen who were, or were suspected to be, supporters of the MDC or related to MDC supporters were subjected to a systematic campaign of gang rape after the 2008 election by members of Zimbabwe's Central Intelligence Organization, pro-Mugabe youth militias, and veterans of the war of liberation" (Howard-Hassmann 2010: 905). After successfully forcing Tsvangirai to withdraw from the runoff round, "[t]he perpetrators of violence... were the beneficiaries of police inaction or party protection, either through 
leaders' pressures on the police or through presidential pardons and amnesties for political crimes" (Kriger 2005: 31).

While repression during (and after) the 2008 Zimbabwean presidential election may seem atypically harsh and perhaps anomalous, Chaturvedi (2005: 190) notes that after the 2002 Zimbabwean election, "violence erupted in the form of beatings, property damage and intimidation around the country." Kriger (2005: 1) argues that Mugabe has actually "used remarkably similar strategies in every general election since 1980." This includes authorizing "vendettas against constituencies that had voted for the opposition" (Kriger 2005: 31). In short, it is possible that the Zimbabwean experience with a runoff rule is not an aberration, but rather, perhaps a runoff rule actually exacerbates any already repressive government's propensity to violate human rights. Mugabe-like dictators may, in effect, be using the first round of a runoff election as a form of intelligence gathering, so that they know whether (or how much) they will need to repress their way to victory in the runoff round.

Human rights scholars have long known that increasing national wealth, reducing overpopulation, and avoiding civil conflict all increase a government's propensity to protect the human rights of its citizens. This study adds that within a democratic context, a runoff rule also increases a government's propensity to protect the human rights of its citizens. For presidential democracies that do not currently have a runoff provision, changing a constitution is often very difficult; however, it is arguably easier to change a constitution than it is to drastically increase wealth, rapidly reduce overpopulation, or suddenly end a long-running civil conflict. Indeed, Keith, Tate, and Poe (2009: 658) note that "from a practical point of view, pursuing better human rights through constitutional law making 
may offer potential for improvement in government respect for human rights that would be difficult to accomplish through attempting to affect other, less manipulable factors." They argue that simply "adopting selected constitutional provisions... has the potential to reduce a nation's level of state terror substantially" (Keith, Tate, and Poe 2009: 644). My findings support this thesis, as I have found that democratic presidential elections held using a runoff rule produce presidents that are less likely to be associated with lower government respect for human rights, and more likely to be associated with greater government respect for human rights. Simply put: a relatively easy way to reduce repression is to add the possibility of a runoff round to all democratic presidential elections. 
Appendix 
Per P5, I argue that in comparison to when the cabinet is comprised of a small percentage of members in the same party as the president, when the cabinet is comprised of a large percentage of members in the same party as the president, that state is less likely to be associated with high government respect for human rights. One could assert that a potential shortcoming of this premise is that while control of key cabinet ministries likely contributes to (or helps to prevent) human rights abuse, many cabinet portfolios (e.g. culture, education, and sports) likely are not very relevant to the protection (or repression) of human rights. Instead of looking at the partisanship of the entire cabinet, perhaps a more clear image of how (and where) repression occurs can be obtained by looking at the cabinet portfolios that have the greatest capacity to repress, such as the ministry of justice. This leads to an alternate version of $\mathbf{P 5}$ :

P5-alternate: In comparison to when the justice minister is not in the same party as the president, when the justice minister is in the same party as the president, that state is less likely to be associated with high government respect for human rights. 
Table 5.1: An additional ordered logit estimate of CIRI scores in presidential democracies, 1990-2011.

\begin{tabular}{lc}
\hline & Model 5 \\
\hline Justice minister in the same party as the president & $-0.493 * *$ \\
& $(0.191)$ \\
Presidential power & $-1.039 *$ \\
& $(0.598)$ \\
Civil conflict & $-1.412 * * *$ \\
& $(0.402)$ \\
Population size & $-0.363 * * *$ \\
& $(0.089)$ \\
GDP per capita & $0.431 * * *$ \\
& $(0.108)$ \\
Previous year's score on the CIRI scale & $1.484 * * *$ \\
& $(0.141)$ \\
Countries & 47 \\
Observations & 430 \\
\hline$* \mathrm{p}<0.10, * * \mathrm{p}<0.05, * * * \mathrm{p}<0.01$. Figures in parentheses are robust \\
standard errors clustered by country. Note that higher values of the dependent \\
variable indicate greater government respect for human rights.
\end{tabular}

In order to test this alternate version of P5, I have constructed the following variable: justice minister in the same party as the president. This variable was constructed using the same sources as my percent of the cabinet in the same party as the president variable (which is detailed in Chapter 3). This new variable, however is coded as follows: every country-year where the justice minister is in the same party as the president is coded as ' 1 ', while every country-year where the justice minister is not in the same party as the president is coded as ' 0 '.

In Table 5.1, I present the results of an ordered logit regression that estimates CIRI scores in presidential democracies from 1990 to 2011. Model 5 in this table tests P5alternate utilizing the same method and the same control variables as Model 2, which 
tested P5. ${ }^{5}$ Consistent with $\mathbf{P 5}$-alternate, Model 5 reports that my primary independent variable is negatively associated with high scores on the CIRI scale, and that this relationship is statistically significant at the $95 \%$ level.

In Table 5.2, I report substantive effects effects of the association between the justice minister being in the same party as the president and high government respect for human rights. Note that these substantive effects are based of the scenarios outlined in Table 4.7, using the same methodology that produced Tables 4.8, 4.9, 4.10, and 4.11 (see Chapter 4 for more details). Again, consistent with P5-alternate, Table 6.2 suggests that states are more likely to experience greater government respect for human rights and less likely to experience lower government respect for human rights when the justice minister is not in the same party as the president.

Many scholars argue that "independent courts constrain states from abusing human rights" (Crabtree and Fariss 2015: 1). ${ }^{6}$ Indeed, Hamilton (2009: 239)—writing in 1788 - argues that "the independence of the judges may be an essential safeguard against the effects of occasional ill humors in the society." " Despite efforts by the judiciary, how-

\footnotetext{
${ }^{5}$ Note that there are substantially more observations (and countries) in Model 5 versus Model 2, despite that the primary independent variables of both models were constructed using the same source material. The reason for this is that it is very difficult to ascertain the political affiliation of every member in a cabinet, which is a prerequisite for calculating the percent of the cabinet in the same party as the president variable. In contrast, it is relatively more manageable to ascertain the political affiliation of only two individuals (i.e. the president and his or her justice minister). As a result, I was able to code many more country-years for my justice minister in the same party as the president variable (versus the relatively few I was able to code for my percent of the cabinet in the same party as the president variable).

${ }^{6}$ Scholars have long emphasized the important role that an independent judiciary plays not only in the functioning of a legal system (Rosenthal 1990), but also in the implementation of human rights legislation (Gibney 1991). An inverse relationship between judicial independence and human rights violations is now widely known to exist; for example, see the following: Cross (1999); Keith (2002b); Hathaway (2007); Powell and Staton (2009). Regimes that protect human rights are generally found to be associated with independent courts (Chavez 2008). Additionally, human rights are expected to be least protected in the states where the courts are most dependent (Epp 1998; Dodson and Jackson 2001).

${ }^{7} \operatorname{Raz}$ (2013: 185) argues that "[t]he rules concerning the independence of the judiciary... are designed to guarantee that they will be free from extraneous pressures and independent of all authority save that of the law," and as such, the rules "are, therefore, essential for the preservation of the rule of law." It is important
} 


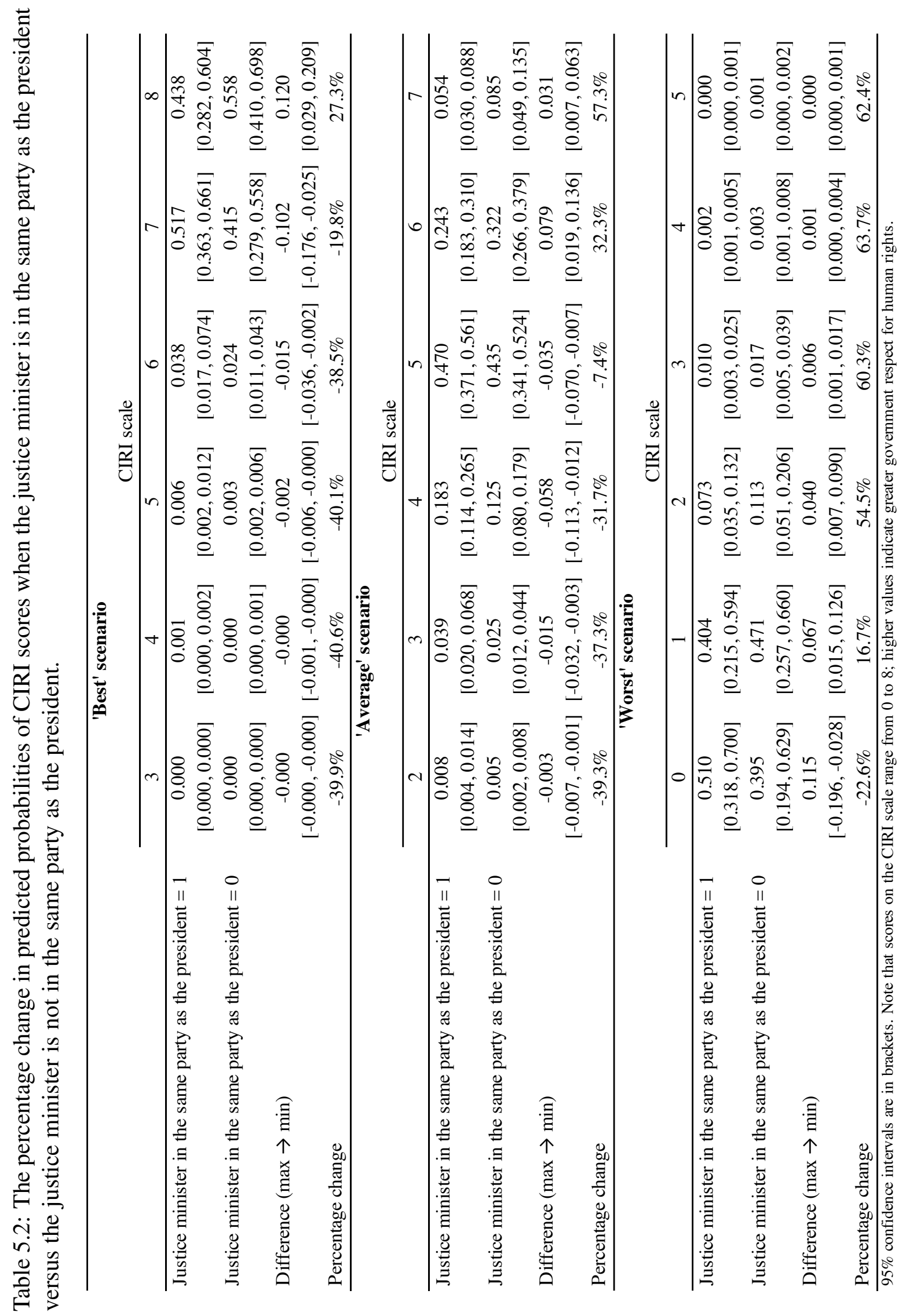


ever, the reality is that courts themselves are not typically responsible for the implementation of their decisions. Hamilton (2009: 236) concedes this point by noting that " $[\mathrm{t}] \mathrm{he}$ judiciary... may truly be said to have neither FORCE nor WILL, but merely judgment; and must ultimately depend upon the aid of the executive arm even for the efficacy of its judgments." In essence, even in a perfect world where courts are independent and judges are fair and just, a court's ultimate decision perhaps matters less than the executive arm's willingness to enforce that court's decision.

Speaking at the 1906 annual convention of the American Bar Association, Pound (1964: 355) argues that "[d]issatisfaction with the administration of justice is as old as the law." With this Appendix, I have sought to shed light on why the administration of justice produces dissatisfaction. When presidents appoint justice ministers from within their own political party, those justice ministers are less likely to disagree with any of the president's ambitions to repress. In such circumstances, a president has a freer hand to infringe upon the rights of citizens. Although courts may try to push back, if the enforcer of court opinions (i.e. the justice minister) is a loyal partisan that answers first to the president, then the administration of justice may be supplanted with the selective administration of injustices. ${ }^{8}$ When a president is denied control of the ministry of justice, however, he or she has a much harder time using that state's justice system (and/or prison apparatus) to violate citizens' rights. ${ }^{9}$

to note, however, that there are conceptual and operational difficulties when defining "the rule of law" (Haggard, MacIntyre, and Tiede 2008). Defining and measuring the "independence" of the judiciary can be just as murky (see Burbank and Friedman 2002).

${ }^{8}$ Alternatively, rather than a president using his or her copartisan justice minister to repress citizens' rights, repressive justice ministers may find themselves less constrained by a copartisan president, and/or more constrained by a president of a different party. Either way, this Appendix warns of the human rights repercussions when one party controls both the presidency and ministry of justice.

${ }^{9}$ Human rights issues are complex and can often impinge on other priorities of a president. Even wellmeaning presidents may come to see greater value in protecting human rights as a result of a justice minister 
While "recent research suggests a strong positive correlation between judicial independence and state government respect for human rights," Crabtree and Fariss (2015: 1) note that "the empirical evidence presented in these studies is mixed." ${ }^{10}$ I propose that perhaps these mixed results are due to court opinions that are not being fully and effectively implemented. Spriggs (1996: 1122), for instance, notes that "[g]overnment bureaucracies are strategic and implement... [c]ourt opinions based upon the costs and benefits of alternative policy choices." The results of this Appendix suggest that in addition to focusing on whether a court arrived at its decision 'independent' of outside influence, we should also be looking at whether the executor of that court decision (i.e. the justice minister) is 'independent' of undue influence. Given the expansive power that justice ministers have with regards to the administration of justice, perhaps this position is best occupied by an individual whose first loyalties are the law and the rights of citizens, rather than political party and presidential piety.

that is able to offer a contrasting perspective by playing 'devil's advocate.'

${ }^{10}$ According to Ríos-Figueroa and Staton (2012: 107), "[t]he primary measurement challenge scholars confront is that judicial independence, however defined, is not directly observable." As a result, Kornhauser (2002: 45) argues "that judicial independence is not a useful, analytic concept." He believes that "confusion over the meaning of judicial independence cannot be eliminated" and that "[d]ebate over these issues of understanding and design would advance more quickly if we abandoned the use of the concept" (Kornhauser 2002: 45). Rubin (2002) goes one step further by challenging the notion that a thing such as 'judicial independence' even exists, given that no court enjoys "complete decisional independence" (Burbank and Friedman 2002: 11-12). 


\section{Bibliography}

Alemán E and Tsebelis G (2011) Political parties and government coalitions in the Americas. Journal of Politics in Latin America 3(1): 3-28.

Alfatooni A and Allen MP (1991). Government sanctions and collective protest in periphery and semiperiphery states. Journal of Political and Military Sociology 19(1): $29-45$.

Altman D (2000) The politics of coalition formation and survival in multiparty presidential democracies: The case of Uruguay, 1989-1999. Party Politics 6(3): 259-283.

Apodaca C (2001) Global economic patterns and personal integrity rights after the Cold War. International Studies Quarterly 45(4): 587-602.

Augenstein D (2016) To whom it may concern: International human rights law and global public goods Indiana Journal of Global Legal Studies 23: 225.

Austin D (1995) Democracy and Violence in India and Sri Lanka (New York: Council on Foreign Relations Press).

Banks AS, Muller TC, and Overstreet WR (eds) (2003) Political Handbook of the World: 2000-2002 (New York: CSA Publications).

Banks AS, Muller TC, and Overstreet WR (eds) (2007) Political Handbook of the World: 2005-2006 (Washington, DC: CQ Press).

Banks AS, Muller TC, and Overstreet WR (eds) (2008) Political Handbook of the World: 2007 (Washington, DC: CQ Press).

Banks AS, Muller TC, and Overstreet WR (eds) (2009) Political Handbook of the World: 2008 (Washington, DC: CQ Press). 
Banks AS, Muller TC, Overstreet WR, and Isacoff JF (eds) (2010) Political Handbook of the World: 2009 (Washington, DC: CQ Press).

Banks AS, Muller TC, Overstreet WR, and Isacoff JF (eds) (2011) Political Handbook of the World: 2010 (Washington, DC: CQ Press).

Banks AS, Muller TC, Overstreet WR, and Isacoff JF (eds) (2012) Political Handbook of the World: 2011 (Washington, DC: CQ Press).

Banks DL (1989) Patterns of oppression: An exploratory analysis of human-rights data. Journal of the American Statistical Association 84(407): 674-681.

Bértoa FC (2016) Database on who governs in Europe and beyond. Available at: https://whogoverns.eu.

Bollen KA (1986) Political rights and political liberties in nations: An evaluation of human rights measures, 1950 to 1984. Human Rights Quarterly 8(4): 567-591.

Boix C and Svolik MW (2013) The foundations of limited authoritarian government: Institutions, commitment, and power-sharing in dictatorships. Journal of Politics 75(2): 300-316.

Booth JA and Seligson MA (eds) (1989) Elections and Democracy in Central America (Chapel Hill, NC: The University of North Carolina Press).

Bordignon M, Nannicini T, and Tabellini G (2016). Moderating political extremism: single round versus runoff elections under plurality rule. American Economic Review 106(8): 2349-70.

Bordignon M, Nannicini T, and Tabellini G (2017) Single round vs. runoff elections under plurality rule: A theoretical analysis. European Journal of Political Economy 49: 123-133.

Bormann N and Golder M (2013) Democratic electoral systems around the world, 19462011. Electoral Studies 32(2): 360-369.

Boswell T and Dixon WJ (1990) Dependency and rebellion: A cross-national analysis. American Sociological Review 55(4): 540-559. 
Boulding KE (1966) Economic Analysis: Volume I Microeconomics, 4th edition (New York: Harper \& Row).

Bouton L (2013) A theory of strategic voting in runoff elections. American Economic Review 103(4): 1248-88.

Bouton L and Gratton G (2015) Majority runoff elections: strategic voting and Duverger's hypothesis. Theoretical Economics 10(2): 283-314.

Brown MB and Forsythe AB (1974) Robust test for the equality of variances. Journal of the American Statistical Association 69: 364-367.

Brusco S, Dziubiński M, and Roy J (2012) The Hotelling-Downs model with runoff voting. Games and Economic Behavior 74(2): 447-469.

Bryce J (1901) Constitutions (Oxford: Oxford University Press).

Bueno de Mesquita B, Downs GW, Smith A, and Cherif FM (2005) Thinking inside the box: A closer look at democracy and human rights. International Studies Quarterly 49(3): 439-457.

Bueno de Mesquita B, Smith A, Siverson RM, and Morrow JD (2003) The Logic of Political Survival (Cambridge, MA: MIT Press).

Burbank SB and Friedman B (2002) Reconsidering judicial independence. In SB Burbank and B Friedman (eds) Judicial Independence at the Crossroads: An Interdisciplinary Approach (Thousand Oaks, CA: Sage).

Camerlo M and Pérez-Liñán A (2015) The politics of minister retention in presidential systems: Technocrats, partisans, and government approval. Comparative Politics 47(3): 315-333.

Chaisty P, Cheeseman N, and Power TJ (2018b) Coalitional presidentialism in comparative perspective: Minority presidents in multiparty systems (Oxford: Oxford University Press).

Chaisty P and Chernykh S (2017) How do minority presidents manage multiparty coalitions? Identifying and analyzing the payoffs to coalition parties in presidential systems. Political Research Quarterly 70(4): 762-777. 
Chaisty P and Power TJ (2019) Flying solo: Explaining singleparty cabinets under minority presidentialism. European Journal of Political Research 58(1): 163-183.

Chavez RB (2008) The rule of law and courts in democratizing regimes. In KE Whittington, RD Kelemen, and GA Caldeira (eds) Oxford Handbook of Law and Politics (Oxford: Oxford University Press).

Cheibub JA (2002) Minority governments, deadlock situations, and the survival of presidential democracies. Comparative Political Studies 35(3): 284-312.

Cheibub JA (2007) Presidentialism, parliamentarism, and democracy (Cambridge: Cambridge University Press).

Cheibub JA, Gandhi J, and Vreeland JR (2010) Democracy and dictatorship revisited. Public Choice 143(1): 67-101.

Cheibub JA, Przeworski A, and Saiegh S (2004) Government coalitions and legislative success under presidentialism and parliamentarism. British Journal of Political Science 34(4): 565-557.

Churchill W and Wall JV (1990) (Boston, MA: South End Press).

Cingranelli DL, Fajardo-Heyward P, and Filippov M (2014) Principals, agents and human rights. British Journal of Political Science 44(3): 605-630.

Cingranelli DL and Filippov M (2010) Electoral rules and incentives to protect human rights. Journal of Politics 72(1): 243-257.

Cingranelli DL and Richards DL (1999a) Measuring the level, pattern, and sequence of government respect for physical integrity rights. International Studies Quarterly 43(2): 407-417.

Cingranelli DL and Richards DL (1999b) Respect for human rights after the end of the Cold War. Journal of Peace Research 36(5): 511-534.

Cingranelli DL and Richards DL (2010) The Cingranelli and Richards (CIRI) human rights data project. Human Rights Quarterly 32(2): 401-424.

Cingranelli DL, Richards DL, and Clay KC (2014) The CIRI Human Rights Project, Version 2014.04.14. Available at: http://www.humanrightsdata.com/p/data-documentation.html. 
Clay KC and Digiuseppe MR (2017) The physical consequences of fiscal flexibility: Sovereign credit and physical integrity rights. British Journal of Political Science 47(4): 783- 807.

Cobban AB (1992) A History of Modern France: Volume 2: From the 1st Empire to the 2nd Empire, 1799-1871 (London: Penguin).

Cohler AM, Miller BC, and Stone HS (1989) Montesquieu: The Spirit of the Laws (Cambridge: Cambridge University Press).

Collier P (2009) Wars, Guns, and Votes: Democracy in Dangerous Places (New York: Harper Perennial).

Collier P and Vicente PC (2012) Violence, bribery, and fraud: The political economy of elections in Sub-Saharan Africa. Public Choice 153(1-2): 117-147.

Conrad CR and Moore WH (2010) What stops the torture? American Journal of Political Science 54(2): 459-476.

Cornett L and Gibney M (2005) Tracking terror: The Political Terror Scale 1980-2001. In Human Security Report 2005: War and Peace in the 21st Century (Oxford: Oxford University Press for the Human Security Centre, University of British Columbia).

Cox GW (1987) Electoral equilibrium under alternative voting institutions. American Journal of Political Science 31(1): 82-108.

Cox GW (1990) Centripetal and centrifugal incentives in electoral systems. American Journal of Political Science 34(4): 903-935.

Cox GW (1997). Making Votes Count: Strategic Coordination in the World's Electoral Systems (Cambridge: Cambridge University Press).

Crabtree CD and Fariss CJ (2015). Uncovering patterns among latent variables: human rights and de facto judicial independence. Research \& Politics 2(3): 1-9.

Cross FB (1999) The relevance of law in human rights protection. International Review of Law and Economics 19(1): 87-98.

Dahl R (1989) Democracy and Its Critics (New Haven, CT: Yale University Press). 
Dalton RJ (1988) Citizen Politics in Western Democracies (Chatham, NJ: Chatham House).

Davenport C (1995) Multi-dimensional threat perception and state repression: An inquiry into why states apply negative sanctions. American Journal of Political Science 39(3): 683-713.

Davenport C (1996a) Constitutional promises' and repressive reality: A cross-national time-series investigation of why political and civil liberties are suppressed. Journal of Politics 58(3): 627-654.

Davenport C (1996b) The weight of the past: Exploring the lagged determinants of political repression. Political Research Quarterly 49(2): 377-405.

Davenport C (1997) From ballots to bullets: an empirical assessment of how national elections influence state uses of political repression. Electoral Studies 16(4): 517-540.

Davenport C (1999) Human rights and the democratic proposition. Journal of Conflict Resolution 43(1): 92-116.

Davenport C (2007) State Repression and the Domestic Democratic Peace (Cambridge: Cambridge University Press).

Davenport C and Armstrong DA (2004) Democracy and the violations of human rights: A statistical analysis from 1976 to 1996. American Journal of Political Science 48(3): 538-554.

Davis DR and Ward MD (1990) They dance alone: deaths and disappeared in contemporary Chile. Journal of Conflict Resolution 34(3): 449-475.

Dodson M and Jackson DW (2001) Judicial independence and instability in Central America. In PH Russell and DM O'Brien (eds) Judicial Independence in the Age of Democracy (Charlottesville: University of Virginia Press).

Doyle D and Elgie R (2016) Maximizing the reliability of cross-national measures of presidential power. British Journal of Political Science 46(4): 731-741.

Downs A (1957) An Economic Theory of Democracy (New York: Harper and Row).

Drury AC and Peksen D (2014) Women and economic statecraft: The negative impact international economic sanctions visit on women. European Journal of International Relations 20(2): 463-490. 
Duvall R and Stohl M (1988) Governance by terror. In M Stohl (ed) The Politics of Terrorism, 3rd edition (New York: Marcel Dekker).

Duverger M (1954) Political Parties: Their Organization and Activity in the Modern State (New York: John Wiley and Sons).

Duverger M (1970) Political Institutions and Constitutional Law (Paris: Presses Universitaire de France).

Duverger M (1980) A new political system model: semi presidential government. European Journal of Political Research 8(2): 165-187.

Epp CR (1998) The Rights Revolution: Activists and Supreme Courts in Comparative Perspective (Chicago: University of Chicago Press).

Fein H (1995) More murder in the middle: Life integrity violations and democracy in the world, 1987. Human Rights Quarterly 17(1): 170-191.

Fisher RA (1934) Statistical methods for research workers, 5th edition. (Edinburgh, Scotland: Oliver \& Boyd).

Francisco RA (1996) Coercion and protest: an empirical test in two democratic states. American Journal of Political Science 40(4): 1179-1204.

Franks CES (ed) (1989) Dissent and the State (New York: Oxford University Press).

Freudenreich $\mathbf{J}$ (2016) The formation of cabinet coalitions in presidential systems. Latin American Politics and Society 58(4): 80-102.

Gartner SS and Regan PM (1996) Threat and repression: The non-linear relationship between government and opposition violence. Journal of Peace Research 33(3): 273287.

Gerring J, Thacker SC, and Moreno C (2005) Centripetal democratic governance: A theory and global inquiry. American Political Science Review 99(4): 567-581.

Gerring J and Thacker SC (2008) A Centripetal Theory of Democratic Governance (Cambridge: Cambridge University Press). 
Gandhi J (2008) Political Institutions under Dictatorship (Cambridge: Cambridge University Press).

Gandhi J and Przeworski A (2006) Cooperation, cooptation, and rebellion under dictatorships. Economics \& Politics 18(1): 1-26.

Gibney M (1991) Courts as "teachers in a vital national seminar" on human rights. In M Gibney (ed) World Justice: U.S. Courts and International Human Rights (Boulder, CO: Westview Press).

Gibney M and Dalton M (1996) The Political Terror Scale. In DL Cingranelli (ed) Human Rights and Developing Countries (Greenwich, CT: JAI Press, Inc).

Gibney M, Cornett L, Wood R, Haschke P, and Arnon D (2015) The political terror scale, 1976-2015 (http://www.politicalterrorscale.org).

Gleditsch N, Wallensteen P, Eriksson M, Sollenberg M, and Strand H (2002) Armed conflict 1946-2001: A new dataset. Journal of Peace Research 39(5): 615-637.

Gurr TR (1986) The political origins of state violence and terror: A theoretical analysis. In M Stohl and GA Lopez (eds) Government Violence and Repression: An Agenda for Research (New York: Greenwood Press).

Haan M and Volkerink B (2001) A runoff system restores the principle of minimum differentiation. European Journal of Political Economy 17(1): 157-162.

Hafner-Burton EM (2008) Sticks and stones: Naming and shaming the human rights enforcement problem. International Organization 62(4): 689-716.

Hafner-Burton EM, Hyde SD, and Jablonski RS (2014) When do governments resort to election violence? British Journal of Political Science 44(01): 149-179.

Hafner-Burton EM and Tsutsui K (2005). Human rights in a globalizing world: The paradox of empty promises. American Journal of Sociology 110(5): 1373-1411.

Hafner-Burton EM and Tsutsui K (2007) Justice lost! The failure of international human rights law to matter where needed most. Journal of Peace Research 44(4): 407425.

Haggard S, MacIntyre A, and Tiede L (2008) The rule of law and economic development. Annual Review of Political Science 11: 205-234. 
Haggard S, McCubbins MD, and Shugart MS (2001) Policy making in presidential systems. In S Haggard and MD McCubbins (eds) Presidents, Parliaments, and Policy (Cambridge: Cambridge University Press).

Hamilton A (2009) Federalist No. 78. In MA Genovese (ed) The Federalist Papers: Alexander Hamilton, James Madison and John Jay (New York: Palgrave Macmillan).

Harff B (2003) No lessons learned from the Holocaust? Assessing risks of genocide and political mass murder since 1955. American Political Science Review 97(1): 57-73.

Hathaway OA (2002) Do human rights treaties make a difference? Yale Law Journal 111(8): 1935-2042.

Hathaway OA (2007) Why do countries commit to human rights treaties? Journal of Conflict Resolution 51(4): 588-621.

Henderson CW (1991) Conditions affecting the use of political repression. Journal of Conflict Resolution 35(1): 120-142.

Henderson CW (1993) Population pressures and political repression. Social Science Quarterly 74(2): 322-333.

Herman ES and Brodhead F (1984) Demonstration Elections: U.S.-Staged Elections in the Dominican Republic, Vietnam, and El Salvador (Boston, MA: South End Press).

Hibbs DA (1973) Mass Political Violence: A Cross-National Causal Analysis (New York: Wiley).

Holzer J (2018) Democratic presidential elections and human rights: does a runoff round reduce repression? The International Journal of Human Rights 22(8): 1087-1110.

Holzer J (2018) The perils of plurality rule and the major(itarian) effect of cabinet composition on human rights in presidential democracies. Research \& Politics 5(3): 1-8.

Holzer J (2019) Measuring presidential centrism and its effect on repression: does ideology influence whether democratic governments respect human rights? Political Science, doi: 10.1080/00323187.2018.1560590. 
Holzer J (2019) When justice answers to the president: reexamining the effect of cabinet partisanship on human rights in presidential democracies. The Social Science Journal, doi: 10.1016/j.soscij.2019.04.006

Horowitz DL (1990) Comparing democratic systems. Journal of Democracy 1(4): 73-79.

Horowitz DL (1991) A Democratic South Africa?: Constitutional Engineering in a Divided Society (Berkeley, CA: University of California Press).

Hotelling H (1929) Stability in competition. The Economic Journal 39(153): 41-57.

Huntington S (1964) The Soldier and the State (New York, NY: Random House).

Kang SG (2009) The influence of presidential heads of state on government formation in European democracies: Empirical evidence. European Journal of Political Research 48(4): 543-572.

Karklins R and Petersen R (1993) Decision calculus of protesters and regimes: Eastern Europe 1989. Journal of Politics 55(3): 588-614.

Keith LC (1999) The United Nations International Covenant on Civil and Political Rights: Does it make a difference in human rights behavior? Journal of Peace Research 36(1): 95-118.

Keith LC (2002a) Constitutional provisions for individual human rights: Are they more than mere "window dressing?" Political Research Quarterly 55(1): 111-43.

Keith LC (2002b) Judicial independence and human rights protection around the world. Judicature 85: 195-200.

Keith LC, Tate CN, and Poe SC (2009) Is the law a mere parchment barrier to human rights abuse? Journal of Politics 71(2): 644-60.

Kim H, and Fording RC (1998) Voter ideology in Western democracies, 1946-1989. European Journal of Political Research 33(1): 73-97.

Kim H, and Fording RC (2003) Voter ideology in Western democracies: An update. European Journal of Political Research 42(1): 95-105.

Kingsbury D (2009) East Timor: The Price of Liberty (Basingstoke, UK: Palgrave Macmillan). 
Kornhauser LA (2002) Is judicial independence a useful concept? In SB Burbank and B Friedman (eds) Judicial Independence at the Crossroads: An Interdisciplinary Approach (Thousand Oaks, CA: Sage).

Krain M (1997) State-sponsored mass murder: The onset and severity of genocides and politicides. Journal of Conflict Resolution 41(3): 331-360.

Laver M and Shepsle KA (1990) Coalitions and cabinet government. American Political Science Review 84(3): 873-890.

Laver M and Schofield N (1998) Multiparty government: The politics of coalition in Europe (Ann Arbor: University of Michigan Press).

Lee DS (2018a) Executive capacity to control legislatures and presidential choice of cabinet ministers in East Asian democracies. Governance 31(4): 777-795.

Lee DS (2018b) Portfolio allocation as the president's calculations: loyalty, copartisanship, and political context in South Korea. Journal of East Asian Studies 18: 345365.

Lehmann P, Matthieß T, Merz N, Regel S, and Weßels, B (2017) The Manifesto Data Collection: South America, Version 2017a. Available at: https://doi.org/10.25522/manifesto.mpdssa.2017a

Levene H (1960) Robust tests for equality of variances. In I Olkin, SG Ghurye, W Hoeffding, WG Madow, and HB Mann (eds) Contributions to Probability and Statistics: Essays in Honor of Harold Hotelling (Menlo Park, CA: Stanford University Press).

Lewis-Beck MS (1990) Economics and Elections: The Major Western Democracies (Ann Arbor, MI: The University of Michigan Press).

Lichbach MI (1987) Deterrence or escalation: the puzzle of aggregate studies of repression and dissent. Journal of Conflict Resolution 31(2): 266-297.

Linz JJ (1990) The perils of presidentialism. Journal of Democracy 1(1): 51-69.

Lipset SM (1963) Political Man: The Social Base of Politics (New York: Anchor Books).

Lijphart A (1977) Democracy in Plural Societies: A Comparative Exploration (New Haven, CT: Yale University Press). 
Lijphart A (1984) Democracies: Patterns of Majoritarian and Consensus Government in Twenty-One Countries (New Haven, CT: Yale University Press).

Lijphart A (1994) Democracies: Forms, performance, and constitutional engineering. European Journal of Political Research 25(1): 1-17.

Lijphart A (1995) Electoral systems. In SM Lipset (ed) The Encyclopedia of Democracy (Washington DC: Congressional Quarterly Press).

Lust-Okar E (2006) Elections under authoritarianism: Preliminary lessons from Jordan. Democratization 13(3): 456-471.

Marshall MG, Gurr TR, and Jaggers K (2014) Polity IV: Political regime characteristics and transitions, 1800-2013 dataset user's manual. Vienna, VA: Center for Systemic Peace (http://www.systemicpeace.org/inscr/p4manualv2013.pdf).

Martínez-Gallardo C and Schleiter P (2015) Choosing whom to trust: Agency risks and cabinet partisanship in presidential democracies. Comparative Political Studies 48(2): 231-264.

Matsushima N (2007) Uncertainty of voters' preferences and differentiation in a runoff system. European Journal of Political Economy 23(4): 1185-1189.

Magaloni B (2006) Voting for Autocracy: Hegemonic Party Survival and its Demise in Mexico (Cambridge: Cambridge University Press).

McCullagh P (1980) Regression models for ordinal data. Journal of the Royal Statistical Society, Series B (Methodological) 42(2): 109-142.

McKelvey, Richard D, and Zavoina W (1975) A statistical model for the analysis of ordinal level dependent variables. Journal of Mathematical Sociology 4(1): 103-120.

McKinlay RD and Cohan AS (1975) A comparative analysis of the political and economic performance of military and civilian regimes. Comparative Politics 8(1): 1-30.

McKinlay RD and Cohan AS (1976) Performance and instability in military and nonmilitary regimes. American Political Science Review 70(3): 850-64.

Meyer W (1996) Human rights and MNCs; Theory versus quantitative analysis. Human Rights Quarterly 18(2): 368-397. 
Mill JS (1977) Considerations on representative government. In JH Robson and A Brady (eds) Essays on Politics and Society (Toronto: University of Toronto Press).

Milnor AJ (1969) Elections and Political Stability: An Analytic Study (Boston, MA: Little, Brown, and Company).

Milza P (2004) Napoléon III (Paris: Perrin).

Mitchell NJ and McCormick JM (1988) Economic and political explanations of human rights violations. World Politics 40(4): 476-98.

Mitchell SM, Ring JJ, and Spellman MK (2013) Domestic legal traditions and states' human rights practices. Journal of Peace Research 50(2): 189-202.

McNitt AD (1995) Government coercion: An exploratory analysis. The Social Science Journal 3(2): 195-205.

Muller TC, Isacoff JF, and Lansford T (eds) (2013) Political Handbook of the World: 2012 (Washington, DC: CQ Press).

Murdie A and Davis DR (2010) Problematic potential: The human rights consequences of peacekeeping interventions in civil wars. Human Rights Quarterly 32(1): 49-72.

Negretto GL (2006) Minority presidents and democratic performance in Latin America. Latin American Politics and Society 48(3): 63-92.

Neto OA (2002) Presidential cabinets, electoral cycles, and coalition discipline in Brazil. In S Morgenstern and B Nacif (eds) Legislative Politics in Latin America (New York: Cambridge University Press).

Neto OA (2006) The presidential calculus: Executive policy making and cabinet formation in the Americas. Comparative Political Studies 39(4): 415-440.

Osborne MJ (1995) Spatial models of political competition under plurality rule: A survey of some explanations of the number of candidates and the positions they take. Canadian Journal of Economics 28(2): 261-301.

Norris P (2004) Electoral Engineering: Voting Rules and Political Behavior (Cambridge: Cambridge University Press). 
Park HS (1987). Correlates of human rights: Global tendencies. Human Rights Quarterly 9(3): 405-13.

Paz y Paz C (2016) Transforming Justice in Guatemala: Strategies and Challenges Investigating Violent Deaths 2011-2014 (Washington, DC: Georgetown University Law Center).

Pérez-Liñán A (2006) Evaluating presidential runoff elections. Electoral Studies 25(1): 129-146.

Pettersson T and Wallensteen P (2015) Armed conflict, 1946-2014. Journal of Peace Research 52(4): 536-550.

Pirages D (1976) Managing Political Conflict (New York: Praeger).

Pitts MJ (2006) Heads or tails? A modest proposal for deciding close elections. Connecticut Law Review 39(2): 739-758.

Piven FF and Cloward RA (1979) Poor People's Movements: Why They Succeed, How they Fail (New York: Vintage Books).

Przeworski A, Alvarez ME, Cheibub JA, and Limongi F (2000) Democracy and development: Political institutions and well-being in the world, 1950-1990 (Cambridge, MA: Cambridge University Press).

Poe SC and Tate CN (1994) Repression of human rights to personal integrity in the 1980s: A global analysis. American Political Science Review 88(4): 853-872.

Poe SC, Tate CN, and Keith LC (1999) Repression of human rights to personal integrity revisited. International Studies Quarterly 43(2): 291-313.

Pound R (1964) The causes of popular dissatisfaction with the administration of justice. Crime \& Delinquency 10(4): 355-371.

Powell GB (2000) Elections as Instruments of Democracy: Majoritarian and Proportional Visions (New Haven, CT: Yale University Press).

Powell EJ and Staton J (2009) Domestic judicial institutions and human rights treaty violation. International Studies Quarterly 53(1): 149-174. 
Raile ED, Pereira C, and Power TJ (2011) The executive toolbox: Building legislative support in a multiparty presidential regime. Political Research Quarterly 64(2): 323-334.

Raz J (2013) The rule of law and its virtue. In A Kavanagh and J Oberdiek (eds) Arguing About Law (London: Routledge).

Regan PM (1995) US economic aid and political repression: An empirical evaluation of US foreign policy. Political Research Quarterly 48(3): 613-628.

Reilly B (2001) Democracy in Divided Societies: Electoral Engineering for Conflict Management (Cambridge: Cambridge University Press).

Reilly B (2002) Electoral systems for divided societies. Journal of Democracy 13(2): 156170.

Reynolds A (1999) Electoral Systems and Democratization in Southern Africa (Oxford: Oxford University Press).

Richards DL (1999) Perilous proxy: Human rights and the presence of national elections. Social Science Quarterly 80(4): 648-665.

Richards DL and Gelleny RD (2007) Good things to those who wait? National elections and government respect for human rights. Journal of Peace Research 44(4): 505523.

Richards DL, Gelleny RD, and Sacko DH (2001) Money with a mean streak? Foreign economic penetration and government respect for human rights in developing countries. International Studies Quarterly 45(2): 219-239.

Richards DL, Webb A, and Clay KC (2015) Respect for physical-integrity rights in the twenty-first century: Evaluating Poe and Tate's model 20 years later. Journal of Human Rights 14(3): 291-311.

Ríos-Figueroa J and Staton JK (2012) An evaluation of cross-national measures of judicial independence. The Journal of Law, Economics, \& Organization 30(1): 104-137.

Robinson JA and Torvik R (2009) The real swing voter's curse. American Economic Review 99(2): 310-315. 
Rose R (1980) Electoral Participation: A Comparative Analysis (Vol. 2) (Beverly Hills: Sage).

Rosenthal AJ (1990) Afterward. In L Henkin and AJ Rosenthal (eds) Constitutionalism and Rights: The Influence of the United States Constitution Abroad (New York: Columbia University Press).

Rubin EL (2002) Independence as a governance mechanism. In SB Burbank and B Friedman (eds) Judicial Independence at the Crossroads: An Interdisciplinary Approach (Thousand Oaks, CA: Sage).

Samuels DJ and Shugart MS (2010) Presidents, parties, and prime ministers: How the separation of powers affects party organization and behavior (Cambridge: Cambridge University Press).

Sartori G (1968) Political development and political engineering. Public Policy 17: 261298.

Sartori G (1994) Comparative Constitutional Engineering: An Inquiry Into Structures, Incentives, and Outcomes (Basingstoke, UK: Palgrave Macmillan).

Satterthwaite FE (1946) An Approximate Distribution of Estimates of Variance Components. Biometrics Bulletin 2: 110-114.

Seligson MA and Booth JA (eds) (1995) Elections and Democracy in Central America, Revisited (Chapel Hill, NC: The University of North Carolina Press).

Shin JH (2013) Cabinet duration in presidential democracies. Political Science Quarterly 128(2): 317-339.

Shugart MS (1999) Presidentialism, parliamentarism, and the provision of collective goods in less-developed countries. Constitutional Political Economy 10(1): 53-88.

Shugart MS (2005) Semi-presidential systems: Dual executive and mixed authority patterns. French Politics, 3(3): 323-351.

Shugart MS and Carey JM (1992) Presidents and Assemblies: Constitutional Design and Electoral Dynamics (Cambridge: Cambridge University Press). 
Shugart MS and Taagepera R (1994) Plurality versus majority election of presidents: A proposal for a "double complement rule". Comparative Political Studies 27(3): 323-348.

Sisk T (1995) Democratization in South Africa: The Elusive Social Contract (Princeton, NJ: Princeton University Press).

Slater D (2004) Indonesia's accountability trap: Party cartels and presidential power after democratic transition. Indonesia 78: 61-92.

Smith J, Bolyard M, and Ippolito A (1999) Human rights and the global economy: A response to Meyer. Human Rights Quarterly 21(1): 207-219.

Sorens J and Ruger W (2012) Does foreign investment really reduce repression? International Studies Quarterly 56(2): 427-436.

Spriggs JF (1996). The supreme court and federal administrative agencies: A resourcebased theory and analysis of judicial impact. American Journal of Political Science 40(4): 1122-1151.

Steiner HJ (1988) Political participation as a human right. In Harvard Human Rights Yearbook (New York: United Nations).

Stiefel M and Wolfe M (1994) A Voice For the Excluded: Popular Participation in Development: Utopia or Necessity (London: Zed Books).

Strouse JC and Claude RP (1976) Empirical comparative rights research: Some preliminary tests of development hypotheses. In RP Claude (ed) Comparative Human Rights (Baltimore, MD: Johns Hopkins University Press).

Taagepera R and Shugart MS (1989) Seats and Votes: The Effects and Determinants of Electoral Systems (New Haven, CT: Yale University Press).

Tarrow SG (1994) Power in Movement: Social Movements, Collective Action and Politics (Cambridge: Cambridge University Press).

Tocqueville A (1896) The Recollections of Alexis Tocqueville (New York: Macmillan, 1896). 
Tomz M, Wittenberg J, and King G (2003) CLARIFY: Software for interpreting and presenting statistical results (Cambridge, MA: Harvard University, Department of Government).

Triossi M (2013) Costly information acquisition. Is it better to toss a coin? Games and Economic Behavior 82: 169-191.

Tsebelis G (2002) Veto Players: How Political Institutions Work (Princeton, NJ: Princeton University Press).

Tufte ER (1974) Data Analysis for Politics and Policy (Englewood Cliffs, NJ: Prentice Hall).

Villalón LA and Idrissa A (2005) Repetitive breakdowns and a decade of experimentation: Institutional choices and unstable democracy in Niger. In LA Villalón and P VonDoepp (eds) The Fate of Africa's Democratic Experiments: Elites and Institutions (Bloomington, IN: Indiana University Press).

Volkens A, Lehmann P, Matthieß T, Merz N, Regel S, and Weßels B (2017): The Manifesto Data Collection, Version 2017a.

Available at: https://doi.org/10.25522/manifesto.mpds.2017a.

Walker N (2016) Human rights and global public goods: The sound of one hand clapping. Indiana Journal of Global Legal Studies 23: 249.

Walker S and Poe SC (2002) Does cultural diversity affect countries respect for human rights? Human Rights Quarterly 24(1): 237-263.

Walter E (1969) Terror and Resistance: A Study of Political Violence (New York: Oxford University Press).

Weiss TG (2000) Governance, good governance and global governance: Conceptual and actual challenges. Third World Quarterly 21(5): 795-814.

Wood RM and Gibney M (2010) The political terror scale (PTS): A re-introduction and a comparison to CIRI. Human Rights Quarterly 32(2): 401-424.

World Bank (2015) World Development Indicators 1960-2014. Available at: http://data.worldbank.org/data- catalog/world-development-indicators. 
Wright J (2008) Do authoritarian institutions constrain? How legislatures affect economic growth and investment. American Journal of Political Science 52(2): 322-343.

Xefteris D (2014) Mixed equilibria in runoff elections. Games and Economic Behavior 87: 619-623.

Yazici E (2019) Nationalism and human rights. Political Research Quarterly 72(1): 147161.

Zanger S (2000) A global analysis of the effect of political regime changes on life integrity violations, 1977-1993. Journal of Peace Research 37(2): 213-233.

Ziegenhagen EA (1986) The Regulation of Political Conflict (New York: Praeger). 


\section{Vita}

Originally from Jefferson City, Missouri, Joshua Holzer completed his undergraduate degree at the University of Denver after serving five years in the United States Army. He later went on to complete graduate degrees at the Monterey Institute of International Studies and the University of Southern California. His work has appeared (or is forthcoming) in Political Science, Research \& Politics, The International Journal of Human Rights, and The Social Science Journal. 